\title{
GCU
}

Glasgow Caledonian

University

University for the Common Good

\section{Estrogenic hormones in São Paulo Waters (Brazil) and their relationship with environmental variables and Sinapis alba phytotoxicity}

Coelho, Lucia Helena Gomes; de Jesus, Tatiane Araújo; Kohatsu, Marcio Yukihiro; Poccia, Geovana Tognella; Chicarolli, Vitor; Helwig, Karin; Hunter, Colin; Roberts, Joanne; Teedon, Paul; Pahl, Ole

Published in:

Water, Air, and Soil Pollution

DOI:

10.1007/s11270-020-04477-2

Publication date:

2020

Document Version

Author accepted manuscript

Link to publication in ResearchOnline

Citation for published version (Harvard):

Coelho, LHG, de Jesus, TA, Kohatsu, MY, Poccia, GT, Chicarolli, V, Helwig, K, Hunter, C, Roberts, J, Teedon, P \& Pahl, O 2020, 'Estrogenic hormones in São Paulo Waters (Brazil) and their relationship with environmental variables and Sinapis alba phytotoxicity', Water, Air, and Soil Pollution, vol. 231, 150.

https://doi.org/10.1007/s11270-020-04477-2

\section{General rights}

Copyright and moral rights for the publications made accessible in the public portal are retained by the authors and/or other copyright owners and it is a condition of accessing publications that users recognise and abide by the legal requirements associated with these rights.

Take down policy

If you believe that this document breaches copyright please view our takedown policy at https://edshare.gcu.ac.uk/id/eprint/5179 for details of how to contact us. 
Estrogenic hormones in São Paulo waters (Brazil) and their relationship with environmental variables and Sinapis alba phytotoxicity

Lucia Helena Gomes Coelho¹ (lucia.coelho@ufabc.edu.br) ORCID: 0000-0002-0175-5734; Tatiane Araújo de Jesus ${ }^{1}$ (tatiane.jesus@ufabc.edu.br) ORCID: 0000-0002-5206-6584; Marcio Yukihiro Kohatsu' (mykohatsu@gmail.com) ORCID: 0000-0003-2998-8780; Geovana Tognella Poccia ${ }^{1}$ (geovana.poccia@gmail.com) ORCID: 0000-0003-2673-9236; Vitor Chicarolli ${ }^{1}$ (vitor_chica@hotmail.com); Karin Helwig ${ }^{2}$ (Karin.Helwig@gcu.ac.uk) ORCID: 0000-0002-9133-5804; Colin Hunter² (Colin.Hunter@gcu.ac.uk) ; Joanne Roberts ${ }^{2}$ (Joanne.Roberts@gcu.ac.uk) ORCID: 0000-0002-6038-7679; Paul Teedon² (Paul.Teedon@gcu.ac.uk) ; Ole Pahl² (le.Pahl@gcu.ac.uk) ORCID: 0000-0002-1317-1672

${ }^{1}$ Federal University of ABC, Avenida dos Estados, 5001, Santo André, SP, Brazil, 09210-580 ${ }^{2}$ Glasgow Caledonian University, Cowcaddens Road, Glasgow, Scotland, UK, G4 OBA 
ABSTRACT

Present study evaluated the relationship between estrogenic hormones concentrations $(17 \alpha-$ ethinylestradiol and 17ß-estradiol) in surface waters in the Metropolitan Region of São Paulo (Brazil) and environmental variables. Four sampling stations were monitored ranging from a protected area to streams discharging human effluent in and around Billings Reservoir. Four sampling campaigns were carried out in each seasonal period: DRY and WET. Samples for hormone analysis (in $\mathrm{ng} \mathrm{L}^{-1}$ ) were concentrated $(1000 \mathrm{X})$ using solid phase extraction $\mathrm{C}_{18}$ cartridges and analysed by liquid chromatography coupled to quadrupole mass spectrometry detection, with $100 \mathrm{ng} \mathrm{L}^{-1}$ limit of quantification. Water temperature, $\mathrm{pH}$, electrical conductivity (EC) and total dissolved solids were determined in situ; total phosphorus and Sinapis alba bioassays were performed subsequently. Reservoir active capacity (AC) and precipitation were also obtained. Estrogenic hormones concentrations were always below limit of quantification at pristine site; at the other sampling stations, $17 \beta$-estradiol concentrations varied from below limit of quantification to $1,720 \mathrm{ng} \mathrm{L}^{-1}$ and $17 \alpha-$ ethinylestradiol from below limit of quantification to $1,200 \mathrm{ng} \mathrm{\textrm {L } ^ { - 1 }}$, with the highest concentrations found in the streams discharging into the reservoir. These streams showed higher Pearson's correlation between 17 $\alpha$-ethinylestradiol, total phosphorus, and electrical conductivity when compared with reservoir stations. Germination index and EC presented negative correlation (Pearson's $\mathrm{r}=-0.61$ ), denoting a phytotoxicity increase with EC increment. $\mathrm{AC}$ influenced the dilution of pollutants and showed negative correlations with total phosphorus (Pearson's $\mathrm{r}=-0.56$ ). These results highlight the relevance of including streams in water monitoring programs, since they are important pollutants loads into watersheds.

Keywords: $17 \alpha$-ethinylestradiol; $17 \beta$-estradiol; electrical conductivity; endocrine disruptors; streams monitoring; water pollution. 


\section{Introduction}

In the last decades, an emerging issue in the area of environmental management is the contamination of the water sources with micropollutants (or so-called pollutants of emerging concern), defined as organic and inorganic compounds that, even at low concentrations (in the order of $\mu \mathrm{g} \mathrm{L}^{-1}$ and $\mathrm{ng} \mathrm{L^{-1 }}$ ), present ecotoxicological risks. These contaminants comprehend a wide range of natural or synthetic chemical compounds, including pharmaceuticals, personal care products (PCPs), hormones, surfactants, flame retardants, pesticides and nanoparticles (Barceló and Petrovic 2008; Quadra et al. 2017). Some chemicals such as phthalates and polychlorinated biphenyls (PCBs) have industrial effluents as their main source of discharge; while pharmaceuticals and personal hygiene products commonly originate from domestic effluents (Ebele et al. 2017).

Among these micropollutants, the group known as endocrine disrupters (EDs) includes exogenous substances that have the capacity to alter organisms endocrine functions, thus causing adverse effects on human health (if ingested) and the aquatic ecosystem (Johns et al. 2011; Rani and Karthikeyan 2016). Although the concentration of these contaminants in the environment is typically low (ng range), adverse effects due to chronic exposure cannot be excluded (Adeel et al. 2017).

Estrogenic hormones are considered responsible for the majority of endocrine effects triggered by the disposal of effluents contaminated with these compounds, since they are very active biologically and are related to the etiology of various types of cancers (Aris et al. 2014; Adeel et al. 2017). Estrogens introduced into the environment may be natural, such as $17 \beta-$ estradiol (E2), estriol, estrone, or synthetic, such as 17 $\alpha$-ethinylestradiol (EE2) and levonorgestrel, developed for use in hormone replacement therapies and contraceptive methods (Reis-Filho et al. 2006; Pereira et al. 2015). These contaminants may occur as parent compounds or in a partially metabolized form. In general $50-80 \%$ of the total parent 
compounds are excreted in the urine and partly in the animal feces as a mixture of metabolized conjugated compounds (Lienert et al. 2007). Women who do not use contraceptives excrete between 10 and $100 \mu \mathrm{g}$ of estrogenic hormones daily, whereas women who are pregnant may excrete up to $30 \mathrm{mg}$ of estrogens per day (Baronti et al. 2000).

Once released into water bodies, compound's physicochemical properties govern its partition between the water, sediment and biomass matrices in an ecosystem. Compounds with low water solubility and high organic phase partition coefficient $\left(k_{o w}\right)$ are generally more present in the adipose tissue of organisms, promoting bioaccumulation along the trophic levels. For example, estrogenic hormones have $\log k_{\text {ow }}$ values ranging from 2.8 to 4.1 , denoting that they are lipophilic (affinity for lipids), poorly soluble in water and more likely to be present in higher concentrations in the biomass, the organic matter that makes up the sediment, or adhered to suspended solids present in the liquid phase of a waterbody (Ebele et al. 2017). However, when excreted by mammals, estrogenic hormones are not in their parental form, but conjugated (i.e. glucuronic acid or sulfate conjugates) which makes them 10 to 50 times more soluble in water (Birkett and Lester 2002; Ebele et al. 2017).

In the European Union (EU), these substances are currently on a Watch List in order to gather monitoring data for the purpose of facilitating the determination of appropriate measures to address the risk posed by those substances (Directive 2013/39/EU). The United States Environmental Protection Agency (USEPA) included these substances in their Third Unregulated Contaminant Monitoring Rule (USEPA 2012). In Brazil, there are still no national regulations that define concentration limits for these compounds in environmental matrices (Padhye and Tezel 2013).

Electrical conductivity (EC) is a normalized measure of the ability of water to conduct an electric current and is directly related to the concentration of dissolved salts in water (Hem 2012). According Su et al. (2017), the monitoring of in-stream EC is a feasible alternative to 
multi-sampling of hydrogeochemical parameters. EC has been widely investigated as a marker of pollution from wastewater discharges (Chalupová et al. 2012; Thompson et al. 2012). EC measurements are therefore useful as a screening tool of pollution levels, indicating loads of anthropogenic contribution. Bonvin et al. (2011) found a strong correlation between EC and concentrations of wastewater-derived micropollutants in Lake Geneva. Total dissolved solids (TDS) measures the combination between all inorganic and organic dissolved substances contained in the water and directly correlates with EC values.

Ecotoxicological bioassays for water quality assessment are an environmental monitoring tool that relate the concentration of xenobiotics to a response in the test organisms (Magalhães and Ferrão-Filho 2008; Silva et al. 2015). Belo (2011) recommends that ecotoxicological bioassays with seeds should be used in an integrated way with other chemical parameters for a better understanding. As an example, Dash (2012) verified the toxicity level of raw sewage samples from Bhubaneswar, India, using rice seeds. The germination index (GI) of rice seeds was $70 \%$ after 3 days incubation, which could be considered as moderately phytotoxic.

Seasonality may affect the water bodies' quality through greater dilution in rainy periods (Girard et al. 2016; Ling et al. 2017). However, Gomes et al. (2019) found inferior water quality in wet season, elucidating impact of catchment laden pollutant runoff. This was in contrast to the common local perception that rainy season would flush out pollutants.

This study is a part of the project Water Environmental Micropollutant Scientific Initiative (WEMSI), a collaborative partnership between Brazil and Scotland.The work objectives were: (I) evaluate the concentrations of selected estrogenic hormones in surface waters of Rio Grande, a Billings Reservoir Branch, , an important drinking water source for Metropolitan Area of São Paulo (MASP) and in streams which inflows this waterbody; (II) examine correlations between the concentrations of these hormones and environmental 
variables, as well as with Sinapis alba bioassays; (III) evaluate the influence of seasonality and reservoir active capacity (AC) in pollutant dilution; (IV) evaluate the relevance of streams monitoring as source of pollutants to the reservoir.

\section{Material and Methods}

\subsection{Study Area}

Billings Reservoir (Figure 1), located in the Tietê River Basin (Cardoso-Silva et al. 2014), is the largest reservoir in MASP with a surface area of 127 million $\mathrm{m}^{2}$ and a maximum depth of $19 \mathrm{~m}$. One of the Billings Reservoir Branches: the Rio Grande, the focus of the present study, is used to supply water to 1.2 million inhabitants of the Greater São Paulo ABC Region (Cardoso-Silva et al. 2014). The waters of Rio Grande Branch are also valuable for amateur fishing; recreation (swimming and boating); landscape aesthetics and agriculture. Unfortunately, this branch also receives raw and treated sewage effluents from legal and illegal surrounding settlements. Preliminary EC monitoring along Rio Grande Branch allowed the selection of four sampling stations reported in Table 1.

\subsection{Sampling}

The climate in MASP is typically dry in winter and wet in summer (Lima and Rueda 2018). Thus, to evaluate the influence of seasonality in pollutant dilution, eight sampling campaigns were undertaken from June 2017 to February 2018. The dry period (April to August) was identified with "D" and in wet period (September to March) was identified with "W". The dry period sampling campaigns were conducted: DI on $13 / 6 / 17$; DII on $19 / 6 / 17$; DIII on $28 / 7 / 17$ \& DIV on $23 / 8 / 17$. The wet period sampling campaigns were conducted: WI on $27 / 10 / 17$; WII on $10 / 11 / 17$; WIII on $7 / 12 / 17 \&$ WIV on $22 / 2 / 17$. Rainfall days were avoided. 
Subsurface water samples were collected in triplicate $(n=3)$ using a Van Dorn bottle and stored in 5-L capacity glass bottles previously cleaned with $1 \mathrm{~mol} \mathrm{~L}^{-1} \mathrm{HCl}(10 \% \mathrm{v} / \mathrm{v})$ and rinsed with deionized water. Field blank containing free water poured into the container in the field was also preserved and shipped to the laboratory. All samples were refrigerated during transportation to the Laboratory of Environmental Analyses of Federal University of ABC for estrogenic hormones analysis, total phosphorus and Sinapis alba bioassays.

\subsection{Reagents}

Analytical standards (EE2 and E2) with purity levels greater than 98\% obtained from Sigma Aldrich were used for the chromatographic analyzes. Organic solvents of High performance liquid chromatography (HPLC) grade with purity $>99.9 \%$ (JT Baker) were used for extraction and elution and American Chemical Society reagent grades (Sigma Aldrich) for total phosphorus analysis and phytotoxicity bioassays.

\subsection{Estrogenic hormones analysis}

Analytical determination of estrogenic hormones was based in EPA Method 539 (USEPA 2010). The glassware used during the analysis were washed with Extran detergent in tap water $(8 \% \mathrm{v} / \mathrm{v})$ and then rinsed with deionized water. The concentration of the estrogenic hormones (E2 and EE2) in water samples was performed using solid phase extraction (SPE) as described by Machado et al. (2014). Briefly the collected samples were filtered through a cellulose acetate membrane $(0.45 \mu \mathrm{m}$ porosity) to remove particulate material and the $\mathrm{pH}$ adjusted to 3.0. SPE cartridges $\left(\mathrm{C}_{18}, 500 \mathrm{mg}, 6 \mathrm{~mL}\right.$, Strata Phenomenex $)$ were conditioned with solvents of increasing polarity (methanol and ultra-pure water) at a flow rate of $5 \mathrm{~mL}$ $\min ^{-1}$ 
After conditioning, 1-liter of filtered aqueous sample was passed through the cartridge to extract the target compounds. The cartridges were stored in a refrigerator prior to Liquid chromatography-mass spectrometry (LC-MS) analysis where the retained compounds were eluted with acetonitrile. The solvent was evaporated in an inert atmosphere at $40{ }^{\circ} \mathrm{C}$ and residual content suspended in $1 \mathrm{~mL}$ of methanol (achieving a 1000X concentration factor).

To assure and control data quality, a QA/QC protocol was planned and systematically implemented along the analytical processes. For SPE blanks were used to assess potential contamination as well as spikes of hormones standards with two-level concentrations used to obtain recovery and accuracy. All experiments were conducted in duplicates to determine analytical precision.

The concentrations of estrogenic hormones were determined using liquid chromatograph (Agilent 1200 Infinity, USA) coupled to a triple quadrupole type mass spectrometer (Agilent 6130, USA).

The simultaneous determination of EE2 and E2 by LC-MS was performed utilizing a $\mathrm{C}_{18}$ column (Zorbax Eclipse Plus, $100 \mathrm{~mm}$ x $4.6 \mathrm{~mm} \times 3.5 \mu \mathrm{m}$, Agilent, USA) at $40{ }^{\circ} \mathrm{C}$ with a mobile phase flow of $0.3 \mathrm{~mL} \mathrm{~min}^{-1}$. The mobile phases consisted of $0.02 \% \mathrm{NH}_{4} \mathrm{OH}$ in water and $0.02 \% \mathrm{NH}_{4} \mathrm{OH}$ in methanol under gradient elution (USEPA 2010). The injection volume was $20 \mu \mathrm{L}$ and detection wavelength at $\lambda=281 \mathrm{~nm}$. After the chromatographic separation, the mobile phase containing the analytes was subjected to the electrospray ionization stage in the mass spectrometer. The ionization source was operated in the negative mode at a voltage of $4000 \mathrm{~V}$. Dry nitrogen gas was used as the carrier at a flow rate of $10 \mathrm{~L} \mathrm{~min}^{-1}$ and a temperature of $350{ }^{\circ} \mathrm{C}$. Estrogenic hormones were identified and quantified using an external calibration method over a concentration range of 100 to $5000 \mu \mathrm{g} \mathrm{\textrm {L } ^ { - 1 }}$. Mass spectra quantification and confirmation were acquired in multiple reaction monitoring (MRM) mode using the $\mathrm{m} / \mathrm{z}$ transitions $295>145$ for EE2 and $271>159$ for E2. 
The limits of detection (LOD) and limits of quantification (LOQ) were determined by injecting progressively lower concentrations of the standard solutions of E2 and EE2 under the chromatographic condition described above. LOD and LOQ were calculated directly from the calibration plot, considering LOD and LOQ as 3 and $10 \rho / \mathrm{S}$, respectively, where $\rho$ is the standard deviation (SD) of intercept and $\mathrm{S}$ is the slope of the calibration curve. For repeatability evaluation, 10 replicate of both compounds were analyzed at three concentration levels $\left(100,500\right.$ and $\left.1000 \mu \mathrm{g} \mathrm{L}^{-1}\right)$.

LC-MS linear calibration curves resulted in Pearson-r $=0.999$ for E2 and 0.997 for EE2. For both compounds, the LOD and LOQ were $30 \mu \mathrm{g} \mathrm{L}^{-1}$ and $100 \mu \mathrm{g} \mathrm{L}^{-1}$, respectively. Considering the concentration factor of 1000, the LC-MS method enabled quantification of $100 \mathrm{ng} \mathrm{L}^{-1}$ of each hormone in water samples. The LC-MS analysis of the 10 replicates at the three selected concentrations showed accuracies between 90 and 97\%, demonstrating good repeatability of the chromatographic method.

The mean recovery for E2 using the Strata SPE cartridges was $89.3 \pm 4.1 \%$ and for EE2 it was $75.7 \pm 4.5 \%$. EPA method 539 (USEPA 2010) outlined the acceptance recovery efficiencies for steroid hormones in water samples. The acceptance criteria are generous, for example, for analysis of E2, the EPA acceptance criteria ranged from 55 to $108 \%$ with Relative Standard Deviations (RSD) of $30 \%$ and from 55 to $110 \%$ with a RSD of $30 \%$ for EE2. Results indicate little sample matrix effect on the extraction procedure and the nonnecessity of further sample clean-up steps which would be more laborious, expensive and time consuming, besides being an extra source of sample contamination.

\subsection{Environmental variables}

Daily precipitation and reservoir active capacity data were obtained from Sabesp (2019). Water temperature, $\mathrm{pH}, \mathrm{EC}$ and TDS were evaluated in the field using a pre-calibrated 
multiparameter probe (Horiba U50, Japan). Total Phosphorus (TP) analysis was conducted at UFABC, with all glassware previously decontaminated with $10 \%(\mathrm{v} / \mathrm{v}) \mathrm{HCl}$ and rinsed with deionized water. Analytical blanks and a calibration curve $\left(0.01-1.0 \mathrm{mg} \mathrm{L}^{-1}\right)$. Water samples were digested in an autoclave using oxidation reagents and the concentrations determined spectrophotometrically (Hach DR 5000, USA) in the visible ultraviolet region (APHA 2012).

\subsection{Sinapis alba bioassays}

Sinapis alba bioassays were performed to assess the phytotoxicity of water samples and followed an adapted methodology based on Belo (2011), ISO 11269-1: 2012, Vieira (2016) and Kohatsu et al. (2018). The experiment consisted of placing a filter paper in a 90 $\mathrm{mm}$ diameter glass Petri dish and moistening with sample $(3 \mathrm{~mL})$ to be tested. Mustard seeds were placed centrally and uniformly (in-line) on the wetted filter paper in each Petri dish. Subsequently, the Petri dishes were capped and wrapped in plastic film to avoid evaporative loss of the sample. The Petri dishes were placed in an upright position with no exposure to light and at $(21 \pm 2){ }^{\circ} \mathrm{C}$ for three days. International Standard Organization (ISO) water (ISO 11269-1: 2012) was used as positive control to determine normal root lengths under optimum conditions and evaluate the seeds quality. The experiments were performed in triplicate.

After the three day period, germination was determined and root length measured with a digital calliper (Mtx, $150 \mathrm{~mm}, 0.01 \mathrm{~mm}$ resolution). Any potential toxic effect was assessed as relative percentage of seed germination $(\% \mathrm{RSG})$, relative percentage of root growth $(\% \mathrm{RRG})$ and the germination index (GI).

To calculate the \%RSG for each plate, equation 1 was used, where $\overline{\bar{S}} g_{s}$ is the arithmetic mean of the number of germinated seeds in the sample; $\overline{\bar{S}} g_{c}$ is the arithmetic mean of the number of germinated seeds in the control.

$$
\% R S G=\frac{\overline{\bar{s}} g_{s}}{\overline{\bar{S}} g_{c}} * 100 \% \quad \text { Equation } 1
$$


The relative percentage of root growth $(\% R R G)$ for each plate was estimated by

equation 2, where $\overline{\bar{L}} r_{s}$ is the arithmetic mean of the root length in the sample; and $\overline{\bar{L}} r_{c}$ is the arithmetic mean of the root length in the control.

$$
\% R R G=\frac{\overline{\bar{L}} r_{s}}{\overline{\bar{L}} r_{c}} * 100 \% \quad \text { Equation } 2
$$

After determining \%RSG and \%RRG, the GI was determined by equation 3:

$$
G I=\frac{\% R S G * \% R R G}{100} \quad \text { Equation } 3
$$

The phytotoxicity of the samples was rated according to Belo (2011): GI > 100\% material enhances germination and root growth of seeds; $80>$ GI $<100 \%$ - no phytotoxic, mature compound; $60>$ GI $<80 \%$ - moderately phytotoxic; $30>$ GI $<60 \%$ - phytotoxic; GI $<$ $30 \%$ - strongly phytotoxic.

\subsection{Statistical analysis}

Analyses of Pearson product moment correlation coefficients were used to determine significant associations between limnological parameters (EC, pH, TDS and TP), hormones concentrations and phytotoxicity results. Strong correlation for Pearson coefficient value lies between \pm 0.50 and \pm 1 , for moderate degree between \pm 0.30 and \pm 0.49 , and low degree below \pm 0.29 (Statstutor 2020). For analysis of variance (ANOVA), a p value $<0.05$ was considered for a significant statistical difference between the evaluated groups. The Tukey's test results were shown by letters above boxplot representations. Levels that are not significantly different from each other are represented with the same letter (e.g.: a, b or c). Pearson correlation analyses, ANOVA statistics and Tukey's tests were done using Microcal Origin 8.1 software.

Principal Components Analysis (PCA) was done to facilitate interpretation of multivariate results and was performed using PAST 3.20 software (Hammer 2001). Limnological data were treated by PCA to identify possible temporal or spatial patterns 
265

266

267

268

269

270

271

272

273

274

275

276

277

278

279

280

281

282

283

284

285

286

287

288

289

among the sampling stations. Factor loadings $>0.7$ are typically regarded as excellent and $<0.3$ very poor. In this study, all principal factors extracted from the variables were retained with eigenvalues $>1.0$ (Yongming et al. 2006).

\section{Results}

\subsection{Estrogenic hormones concentration}

E2 and EE2 levels during the eight sampling campaigns are shown in Table 2. Concentrations of both compounds at station S1 (Reference) were below LOQ (100 ng L $\left.{ }^{-1}\right)$ in all the sampling campaigns. Station S3 (Ribeirão Pires stream) measurable E2 was found in all campaigns $\left(110-1,700 \mathrm{ng} \mathrm{L^{-1 } )}\right.$ and EE2 in six $\left(210-1,200 \mathrm{ng} \mathrm{L}^{-1}\right)$. The $\mathrm{S} 4$ sampling station, Tubarão stream, yielded E2 in five campaigns $\left(300-1,720 \mathrm{ng} \mathrm{L}^{-1}\right)$ and EE2 in seven $\left(120-650 \mathrm{ng} \mathrm{L}^{-1}\right)$.

\subsection{Environmental variables monitoring}

Precipitation data $(\mathrm{mm})$ within the studied area, together with the Rio Grande active capacity (AC, \%) and sampling campaign dates are presented in Figure 2. Total rainfall during the study period was $1157 \mathrm{~mm}$, with 39\% in dry (April - August) and 61\% in wet (September-March) periods, respectively. The AC (\%) showed a different pattern, with a greater capacity $(>70 \%)$ at sampling DI, DII and WIV. Whereas sampling campaigns WI, WII and DIII occurred when the reservoir was operating at around $65 \%$ capacity. This indicates environmental dilution during the dry sampling campaigns could be typically greater than that in the wet sampling campaigns.

Figure 3 shows environmental variables boxplots and ANOVA results with Tukey's test. Water temperature was higher in the wet than in the dry season, but no statistical difference was observed seasonally or spatially. Considering seasonal variation no statistical 
difference was observed within EC, TDS and TP, which might have been influenced by AC variability. However, for these parameters, ANOVA results showed spatial significant differences among stations located in the reservoir (S1 and S2) and in the streams (S3 and S4), evidencing the contribution of the streams to pollution loads in the reservoir with subsequent dilution effect.

The mean GI value for samples from the dry period was $83.16 \pm 0.32 \%$ and the wet season $82.74 \pm 0.37 \%$ (both no phytotoxic). S3 was the only station where the GI value in both periods was classified as moderately phytotoxic (GI between 60 and 80\%). Overall, no seasonal difference among GI values was observed.

\subsection{PCA of Reservoir stations}

Figure 4 shows PCA results obtained using the general indicators of anthropogenic pollution to reservoir stations (S1 and S2). The first two components explained $97.7 \%$ of the total variance. The PC1 represents $78.4 \%$ of the data variability and the most influential variables are EC, TDS, $\mathrm{pH}$ and GI. PC2 explained 19.2\% of the variance, where EC, TDS, and TP are the variables with more influence. Temperature $(\mathrm{T})$ is the most important factor in the PC3, which explains $1.8 \%$. This PCA analysis shows clearly that TDS and EC are highly correlated.

The score graph do not shows the separation of sites S1 and S2 into different groups, which may not mean that there is no distinction, and could simply mean that largest sources of variation are similar in both groups. Water samples from sampling campaigns D1-S1, D1S2, and WII-S2 showed the highest values of the EC, TDS and TP suggesting no existence of spatial and seasonal trends in the pollutant concentrations in the reservoir. The loading graphic permits to observe that EC and TDS showed high positive correlation among themselves and strong negative with TP. 
Figure $5(\mathrm{a}-\mathrm{c})$ shows the Pearson's correlation coefficients for $\mathrm{AC}\left(\mathrm{r}_{\mathrm{S} 1}=-0.59\right.$ and $\mathrm{r}_{\mathrm{S} 2}=$ $-0.89)$, TP $(r=-0.56)$ and GI $(r=-0.61)$ with respect to EC values obtained to reservoir stations (S1 and S2).

\subsection{PCA of Streams stations}

Figure 6 shows PCA with estrogenic hormones concentration, GI and limnological parameters for the streams stations (S3 and S4). The first two components explained $91.9 \%$ of the total variance. The PC1 represents $63.4 \%$ of the data variability and the most influential variables are E2 and EE2 concentrations and PC2 explained $28.7 \%$ of the variance, where TP most influenced the results.

The score graph do not shows spatial distinction between streams S3 and S4 which might indicate that largest sources of variation are similar in both groups. Neither seasonal group distinction was observed within data. The loading graphic permits to observe that E2 levels most influenced PCA with no significant correlation to common indicators of anthropogenic pollution (e.g.: EC and TP).

\section{Discussion}

\subsection{Presence of hormones in Rio Grande waters and adjacent streams}

The development of more selective and sensitive analytical techniques has allowed the identification and quantification of these active estrogenic compounds in low concentrations in aquatic environments from different parts of the world (Zuccato et al. 2005; Nakada et al. 2006; Kim et al. 2007; Benotti et al. 2009; Kummerer 2009; Sui et al. 2010; Gracia-Lor et al. 2012; Tran et al. 2018).

At present study, estrogenic hormones levels were not detected at station S1, reflecting the preservation status of this area, which is less impacted by anthropogenic sources. Sousa et 
al. (2014) evaluated different emerging pollutants in river water from metropolitan region of São Paulo and Campinas city and did not find detectable E2 and EE2. Even in very clear water, hormones have been reported in the literature, for example, Scala-Benuzzi et al. (2018) found $8.2 \mathrm{ng} \mathrm{L}^{-1}$ of EE2 in pristine river waters in Argentina. Caldwell et al. (2012) noted that reported concentrations in the United States and Europe reach about 0.2 or $0.3 \mathrm{ng} \mathrm{L}^{-1}$ in low flow conditions, and caution against studies that report higher concentrations as unrepresentative.

At present work, station S2, closer to precarious urbanization with inadequate wastewater disposal and a drinking water abstraction point, yielded measurable E2 levels in three campaigns $\left(860-900 \mathrm{ng} \mathrm{L^{-1 }}\right)$ and EE2 in two campaigns $\left(210\right.$ and $\left.630 \mathrm{ng} \mathrm{L^{-1 }}\right)$. This is possibly due to input of raw or inefficiently treated wastewater into the ecosystem. Ghiselli (2006) reported E2 at 1,800 to $6,000 \mathrm{ng} \mathrm{L}^{-1}$ and EE2 at 1,000 to 3,500 $\mathrm{ng} \mathrm{L}^{-1}$ in surface water in Campinas, Brazil. Other Brazilian studies have indicated levels in the order of $500 \mathrm{ng} \mathrm{L}^{-1}$ of estrogenic hormones in the Atibaia River, which supplies 92\% of Campinas city (Ghiselli and Jardim 2007; Sodré et al. 2010; Maldaner and Jardim 2012). Sodré et al. (2010) identified E2 and EE2 levels, which reached 2,510 and $310 \mathrm{ng} \mathrm{L}^{-1}$, respectively, at places located along the Atibaia River watershed.

Levels of estrogen hormones in effluents might be higher even after wastewater treatment by conventional technologies. Pessoa et al. (2014) found estrogen levels in the effluent of a Brazilian WWTP between $<$ LOD to $776 \mathrm{ng} \mathrm{L}^{-1}$ and $3,180 \mathrm{ng} \mathrm{\textrm {L } ^ { - 1 }}$ for raw wastewater and 397 and $176 \mathrm{ng} \mathrm{L}^{-1}$ for activated sludge treated effluent (for E2 and EE2, respectively). These values are of similar magnitude to the concentrations detected in the present study at locations S3 and S4.

Ashfaq et al. (2018) quantified these hormones in influent wastewater in China and reported EE2 concentrations from $<$ LOD to $4.04 \mathrm{ng} \mathrm{L}^{-1}$, but much higher levels of E2 of 46 to 
$150 \mathrm{ng} \mathrm{L^{-1 }}$. In Europe, concentrations reported in a review paper by Schröder et al. (2016) remain below $97 \mathrm{ng} \mathrm{L}^{-1}$ (E2) and $106 \mathrm{ng} \mathrm{L}^{-1}$ (EE2) in WWTP influent. Vymazal et al. (2015) in Czech Republic didn't detected EE2 in influent wastewater but found levels of E2 from

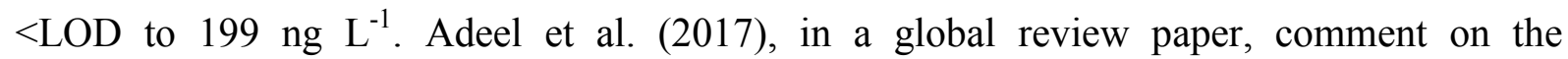
particularly high levels of some estrogenic hormones in Brazil. Thus, in the Brazilian context of inadequate sewage treatment, high concentrations should not be dismissed out of hand as and may indeed be cause for concern.

All mammals excrete estrogenic hormones, which end up in the environment through direct excretion or through animal waste disposal. Multiple biological effects resulting from the exposure to E2 and EE2 have been described in the literature. In humans, the binding affinity of EE2 to the estrogen receptor is higher than for E2, and has been shown to be up to five times higher in some fish species (Aris et al. 2014). This higher affinity indicates that EE2 can be a more potent estrogenic compound in terms of endocrine disrupting effect compared to the naturally produced E2 (Tomšíková et al. 2012). For example, when early life stages of the zebrafish (Danio rerio) were exposed to $54 \mathrm{ng} \mathrm{L}^{-1}$ of E2, sex ratio was significantly altered (Holbech et al. 2006). EE2 determined in water courses is cause for concern as its estrogenic potency is twenty-five times higher in in vitro tests using Zebra fish compared to E2 (van der Belt et al. 2004; Andrew et al. 2010).

E2 and EC had a weak correlation (Pearson's $r=0.21$ ) (Figure 7c). This can be explained by E2 sources and biodegradation rates in the environment. Ma and Yates (2018) evaluated E2 degradation in batch assays using river and sediment samples from Santa Ana River (USA). The study reported higher E2 degradation rates in the presence of microorganisms, especially in assays with sediment samples where microbiological density was higher: E2 degradation in water took 10 days and in sediment about 2 days. E2 is typically excreted in conjugated forms such as sulfate and glucuronide which the 
microorganisms de-conjugate back to parental estradiol. These results supports the low correlation between E2 and EC in the present study, due to their excretion in the conjugated form, which is not detected by the LC-MS method and also by the faster degradation rates of this compound in polluted water containing microorganisms from wastewater, such as Escherichia coli. However, as expected, EE2 and EC had a strong correlation (Pearson's r = 0.71). EE2 is more resistant to biodegradation than E2 and remains stable even after wastewater treatment by activated sludge process (Panter et al. 1999; Aris et al. 2014). This support the higher correlation between EE2 and EC in the present study that involved sampling stations with raw wastewater disposal (S4) and treated effluent from WWTP (S3), reinforcing the persistence and detectability of EE2.

At present study, given that half of the sampling sites were locations where human pollutants would be well diluted (reservoir), the overall average E2 (650 $\left.\mathrm{ng} \mathrm{L}^{-1}\right)$ and EE2 (720 $\mathrm{ng} \mathrm{L^{-1 }}$ ) is of environmental concern. These are $10 \mathrm{x}$ and $3000 \mathrm{x}$ the reported $\mathrm{EC}_{50}$ values to Zebra fish for E2 and EE2 respectively (Figure 8) and are likely to occur in association with other emerging pollutants (van den Belt et al. 2004). This clearly demonstrates the need to eliminate discharge of raw sewage into Brazilian watercourses and to improve existing wastewater treatment procedures and plants, as well include streams in environmental monitoring to avoid pollution of waterbodies used to water supply.

\subsection{Spatial distribution of pollutants}

During this study, EC and TDS values were one order of magnitude higher in the two streams compared to sampling stations in the reservoir, indicating the influence of anthropogenic sources on the streams. In fact, EC is pointed as a domestic sewage marker (Sousa et al. 2014), since each person consumes an average of $6 \mathrm{~g}$ of chloride per day (WHO 2003), which increases chloride ion concentrations in effluents. In opposite, undisturbed 
415

416

417

catchments are characterized by very low in-stream ionic concentrations and by EC $<10 \mu \mathrm{S}$ $\mathrm{cm}^{-1}$ (Markewitz et al. 2006). Yet, EC can be used too assessing water discharge, since these parameters have an inverse relationship due to the fact that new water contributing to runoff has shorter residence time than old water and hence lower ionic content (Weijs et al. 2013; Cano-Paoli 2019).

Unexpected, S3 and S4 showed similar pollution levels, despite their difference in discharge content. S3 is a water body which receives huge quantity of raw sewage from Ribeirão Pires municipality. S4 receives effluent from a secondary level WWTP, rich in P. This can be explained by the dilution effect in S3, which has a higher flow capacity, which reduces pollution effects (Gomes et al. 2014, 2019). However, hydrological data of the studied streams are not available, and this is a reality in tropical areas, where hydrological data use to be very scarce (Hartemink et al. 2008, Rodrigues et al. 2018).

For all the monitoring stations, the concentration of TP exceeded the Brazilian Standards limit value (Brasil 2005), even at the reference station (S1), reinforcing the anthropogenic contribution by sewage in the reservoir and necessity of to improve sanitation in the Rio Grande basin, aiming the eutrophication control (Mariani et al. 2006; MoschiniCarlos et al. 2010; Wengrat and Bicudo 2011).

\subsection{Seasonal variation of pollutants concentration}

Rangel-Peraza et al. (2009) showed that water quality parameters have seasonal responses in large Tropical reservoirs, especially for temperature, electrical conductivity, biochemical oxygen demand and total coliforms. In general, wet season may cause soil erosion and bring eroded material to the water body. The dry season may cause river water lost through evaporation, increasing concentrations of suspended materials and dissolved elements (Nguyen et al. 2020). 
Rio Grande basin presents two distinct rainfall seasons: wet and dry. Wet season is characterized by higher temperatures. AC presented a strong negative correlation with EC, especially for S2 station thus the lower volume of the reservoir concentrated chemical species enhancing electrical conductivity. For the estrogenic hormones, the weak correlations might be related to their lipophilicity ( $\log \mathrm{k}_{\mathrm{ow}}, \mathrm{E} 2=4.0$ and $\log \mathrm{k}_{\mathrm{ow}}$ EE2 $=3.7$ ), partitioning mainly into particle and sediment phases rather than being present in water column, thus not presenting a direct correlation with the dissolved ions responsible for EC. Regarding GI, a negative strong correlation with EC indicates that higher levels of pollution can increase water toxicity, reflecting in lower GI values. As expected, both in dry and wet seasons, GI was less affected at control station S1.

Our findings indicated higher mean values of EC, TDS, TP and low GI (more phytotoxic) to streams (S3 and S4) during the dry season, but without a statistical difference (Figure 3). This can be explained by low rain volume to dilute pollutants in the dry season in the streams. These findings are in according to Coulibaly et al. (2012) who found higher metal $(\mathrm{Hg}, \mathrm{Cd}, \mathrm{Pb}$, and $\mathrm{Zn})$ concentrations in the dry season than in the rainy season in sediments from Biétri Bay in Ebrié Lagoon, Ivory Coast. These authors attributed this to "reduced water volume during the dry season". Strong correlation between TP and EC and a medium one between GI and EC were observed, as expected, since streams receive domestic wastewater and treated effluent from WWTP loads and are more affected by precipitation dilution. It is noteworthy that only two abundant rainfalls (greater than $20 \mathrm{~mm}$ ) occurred in the 2 days prior to sampling (DIV and WI). Rodrigues et al. (2018) found higher discharge values in the rainy season. To these authors, $\mathrm{pH}$ and $\mathrm{EC}$ were higher probably because sewers can discharge via combined sewer overflows an input of water flow to the main stream channel during intense rainstorms which was not observed in the study. 
The $\mathrm{pH}$ had a statistical difference between stations and seasonality (Figure 3 ). This could be due to eutrophication process. Algal blooms in Rio Grande Branch mainly occur in summer, between the months of December and March (wet period), due to increased run-off, but this also depends on reservoir active capacity, which might dilute these effects (Leal et al. 2018). These blooms tend to consume $\mathrm{CO}_{2}$ from water during photosynthesis and thus contribute to $\mathrm{pH}$ increase (Tailing 2010; Brasil et al. 2016). Bicudo et al. (2007) obtained a strong positive correlation between $\mathrm{CO}_{2}$ and water transparency, as well as strong negative correlations of these variables with chlorophyll-a and $\mathrm{pH}$, when evaluating data from a hypereutrophic lentic aquatic ecosystem in Brazil before and after removal of aquatic macrophytes and subsequent dominance of cyanobacteria. Before removal of the macrophytes, the $\mathrm{pH}$ was always neutral to slightly acid and free $\mathrm{CO}_{2}$ was around $30 \mathrm{mg} \mathrm{L}^{-1}$. After removal of the macrophytes and with the subsequent dominance of the cyanobacteria, the $\mathrm{pH}$ was always above 7 , reaching almost 11 and free $\mathrm{CO}_{2}$ decreased dramatically.

Algal blooms frequently occur around station S2 which is close to the drinking water abstraction location, therefore the Sanitation Company of the state of São Paulo applies copper sulfate and hydrogen peroxide for phytoplankton and cyanobacteria control in this area (Sabesp 2011). Cyanobacteria lead to socioeconomic problems once toxins released degrades organoleptic water characteristics such as odor and taste, enhancing the cost of water treatment (Leal et al. 2018). Chronic ingestion to levels of $\mathrm{CuSO}_{4}$ may cause respiratory inflammation, hepatotoxicity, and loss of fertility in humans (Huh and Ahn 2017). In developed countries the use of $\mathrm{CuSO}_{4}$ as an algaecide was abolished (Codd et al. 2005). However, in Brazil, it is still one of the most used cyanobacteria control methods due to its low cost and effectiveness (Leal et al. 2018). Additionally, $\mathrm{pH}$ might increase due to residual copper hydrolysis (Souza and Wasserman 2015). 
GI values for reservoir stations S1 and S2 were lower (i.e. more toxic) in the wet season than in the dry period. In the wet season, it was expected that the dilution factor would decrease the toxicity, given that the rainfall volume was generally higher, despite this AC was typically higher in dry period. Thus, the dilution factor was not the dominant factor in GI of the samples. The opposite was observed with samples taken from the streams S3 and S4 where, as expected, the dry season samples were more toxic.

\subsection{Streams monitoring relevance}

Stream monitoring supports water resource management in recognize segments severely impaired requiring remediation; identify priority pollutants that might achieve watersheds; prioritize watersheds for restoration; assess effectiveness of storm water management retrofits to capture, slow down, and filter water run-off; track progress in meeting water quality goals and legally mandated water quality standards; and assess and track the health of the watershed ecological functions (US Forest Service 1995; Ziemer 1998). Freshwater environments offer many ecosystem services for the society such as water, food, water purification, genetic resources, regulation of water flow, recreation and aesthetic aspects (Harrison et al. 2010; Schäfer et al. 2012). In this context, streams have hydrological functions in the environment once they receive direct discharge of wastewater. These pollutant loads are diluted by stream flowrates and are biochemically transformed by the microorganisms present in these ecosystems (Thompson et al. 2018). However, environmental degradation have been threatening these ecosystems functions, especially by the provision of pollutants that change natural characteristics of the environment, as well as presenting some toxicity level to the biota (MEA 2005). For example the release of treated sewage (Pereda et al., 2020) and nanoparticles (Du et al. 2019) may affect ecosystem functions. Pereda et al. (2020) carried out an experiment in a stream, evaluating the influence 
513 of effluent discharge from a WWTP on the biota and stream's function. They concluded that 514 structure and functioning of the ecosystem was affected even with well treated and highly 515 diluted discharges. Du et al. (2019) concluded that after a certain dosage of nanoparticles 516 (from 10 to $1000 \mathrm{mg} \mathrm{L}^{-1}$ of $\mathrm{ZnO}$ ), there was a reduction in fungi diversity, which affects the 517 decomposition and the environment ecological functions.

These functions highlight the streams importance as attenuators to ingress of

\section{Conclusions}

This leads us to following main conclusions:

- E2 concentrations varied from $<$ LOQ to $1,720 \mathrm{ng} \mathrm{L}^{-1}$ and EE2 from $<$ LOQ to 1,200 ng $\mathrm{L}^{-1}$, with the highest levels being present in the two streams, contaminated with raw and treated domestic wastewater, that feed into Billings reservoir. For both of these compounds, this exceeds PNEC and NOEC levels by at least an order of magnitude, indicating a very high ecotoxicological risk in the investigated area and giving rise to possible concern for concentrations in drinking water.

- Stream monitoring stations showed higher correlations between TP, GI and EE2 with EC, which indicates wastewater discharge into the streams. Thus, EC is a good marker for these variables in streams and reinforces their relevance for inclusion in water quality monitoring programs. Seasonality influences precipitation and active capacity of the reservoir. These variables influenced the pollutant dilution in present study. 
This reinforces the necessity of including hydraulic and hydrological data in environmental monitoring. Unfortunately, this kind of data is very scarce in tropical regions yet.

- The findings in this paper emphasis the importance of including streams in water quality monitoring programs; not only because of ecotoxicological impacts in these water bodies themselves, but also because they are important as pathways for pollutants to reservoirs, which are used for fishing, bathing and drinking water abstraction.

\section{Acknowledgments}

The authors are grateful to British Council, Newton Fund and CAPES (Coordination for Improvement of Higher Education Personnel) for project funding (process number 004/16), as well as to FAPESP for the Scientific Initiation Grant awarded to M.Y.K. (Process 2017/082341). We also thank Multiuser Experimental Central facilities of UFABC and trainees by field and laboratory support.

\section{Conflict of interest}

This work was supported by CAPES (Grant Number 004/16) and NEWTON FUND (Grant Number 72728076). The authors declare that they have no conflict of interest. 


\section{References}

Adeel, M., Song, X., Wang, Y., Francis, D., Yang, Y. (2017). Environmental impact of estrogens on human, animal and plant life: A critical review. Environmental International, 99, 107-119.

Andrew, M.N., O'Connor, W.A., Dunstan, R.H., MacFarlane, G.R. (2010). Exposure to 17aethynylestradiol causes dose ad temporally dependent changes in intersex, females and vitellogenin production in the Sydney rock oyster. Ecotoxicology, 19, 1440-1451.

APHA (2012). Standard Methods for the Examination of Water and Wastewater. American Public Health Association, $22^{\text {nd }}$ Ed., Washington.

Aris, A.Z., Shamsuddin, A.S., Praveena, S.M. (2014). Occurrence of 17 $\alpha$-ethynylestradiol (EE2) in the environment and effect on exposed biota: a review. Environmental International, 69, 104-119.

Ashfaq, M., Li, Y., Wang, Y., Qin, D., Rehman, M.S.U., Rashid, A., Yu, C.P., Sun, Q. (2018). Monitoring and mass balance analysis of endocrine disrupting compounds and their transformation products in an anaerobic-anoxic-oxic wastewater treatment system in Xiamen, China. Chemosphere, 204, 170-177.

Barceló, D., Petrovic, M. (2008). Emerging contaminants from industrial and municipal waste: occurrence, analysis and effects. Ed. Springer, Berlin, 192 p.

Baronti, C., Curini, R., D’Ascenzo, G., Corcia, A., Gentilli, A., Samperi, R. (2000). Monitoring natural and synthetic estrogens at activated sludge sewage treatment plants and in a receiving river water. Environmental Science and Technology, 34, 5059-5066.

Belo, S.R. (2011). Avaliação de fitotoxicidade através de Lepidium sativum no âmbito de processos de compostagem. [Evaluation of phytotoxicity through Lepidium sativum in the context of composting processes] Masters Dissertation, Universidade de Coimbra, Portugal, 79 p. 
583 Benoti, M.J., Trenholm, R.A., Vanderford, B.J., Holady, J.C., Stanford, B.D., Snyder, S.A.

584

585

586

587

588

589

590

591

592

593

594

595

596

597

598

599

600

601

602

603

604

605

606 (2009). Pharmaceuticals and Endocrine Disrupting Compounds in U.S. Drinking Water. Environmental Science and Technology, 43(3), 597-603.

Bicudo, D.C., Fonseca, B.M., Bini, L.M., Crossetti, L.O., Bicudo, C.E.M., Jesus, T.A. (2007). Undesirable side-effects of water hyacinth control in a shallow tropical reservoir. Freshwater Biology, 52, 1120-1133.

Birkett, J.W., Lester, J.N. (Eds.) (2002). Endocrine disruptors in wastewater and sludge treatment processes. Lewis Publishers, Boca Raton, 312p.

Bonvin, F., Rutler, R., Chevre, N., Halder, J., Kohn, T. (2011). Spatial and Temporal Presence of a Wastewater-Derived Micropollutant Plume in Lake Geneva. Environmental Science and Technology, 45, 4702-4709.

Brasil (2005). CONAMA: Conselho Nacional do Meio Ambiente [National Council for the Environment]. Resolution n. ${ }^{\circ}$ 357. Brasília, DF. Brazil. 27 p. Available in: http://www.mma.gov.br/port/conama/legiabre.cfm?codlegi=459. Accessed in 30 July 2018.

Brasil, J., Attayde, J.L., Vasconcelos, F.R., Dantas, D.D.F., Huszar, V.L.M. (2016). Droughtinduced water-level reduction favors cyanobacteria blooms in tropical shallow lakes. Hydrobiologia, 770, 145-164.

Caldwell, D.J., Mastrocco, F., Anderson, P.D., Länge, R., Sumpter, J.P. (2012). Predicted-noeffect concentrations for the steroid estrogens estrone, $17 \beta$-estradiol, estriol, and $17 \alpha-$ ethinylestradiol. Environmental Toxicology Chemistry, 31(6), 1396-1406.

Cano-Paoli, K., Chiogna, G., Bellin, A. (2019). Convenient use of electrical conductivity measurements to investigate hydrological process in Alpine headwaters. Science of the Total Environment, 685, 37- 49. 
607

608

609

610

611

612

613

614

615

616

617

618

619

620

621

622

623

624

625

626

627

628

629

630

Cardoso-Silva, S., Nishimura, P.Y., Padial, P.R., Mariani, C.F., Moschini-Carlos, V., Pompêo, M.L.M. (2014). Compartimentalização e qualidade da água: o caso da Represa Billings. Bioikos Campinas, 28(1), 31-43.

Chalupová, D., Havlíková, P., Janský, B. (2012). Water quality of selected fluvial lakes in the context of the Elbe River pollution and anthropogenic activities in the floodplain. Environmental Monitoring Assessment, 184, 6283-6295.

Codd, G.A., Azevedo, S.M.F.O., Bagchi, S.N., Burch, M.D., Carmichael, W.W., Harding, W.R., Kaya, K., Utkilen, H.C. (2005). CYANONET: a global network for cyanobacterial bloom and toxin risk management. Initial Situation Assessment and Recommendations, International Hydrological Programme, UNESCO, Paris, France.

Coulibaly, S., Atse, B.C., Koffi, K.M., Sylla, S., Konan, K.J. Kouassi, N.G.J. (2012). Seasonal Accumulations of Some Heavy Metal in Water, Sediment and Tissues of Black-Chinned Tilapia Sarotherodon melanotheron from Biétri Bay in Ebrié Lagoon, Ivory Coast. Bulletin of Environmental Contamination and Toxicology, 88, 571-576.

Dash, A.K. (2012). Impact of domestic wastewater on seed germination and physiological parameters of rice and wheat. International Journal of Recent Research and Applied Studies, 12(2), 280-286.

Directive 2013/39/EU of the European Parliament and of the Council of 12 August 2013 amending Directives 2000/60/EC and 2008/105/EC as regards priority substances in the field of water policy. https://eur-lex.europa.eu/eli/dir/2013/39/oj. Accessed 19 December 2018.

Du, J., Zhang, Y., Guo, R., Meng, F., Gao, Y., Ma, C., Zhang, H. (2019). Harmful effect of nanoparticles on the functions of freshwater ecosystems: Insight into nanoZnO-polluted stream. Chemosphere, 214, 830-838. 
631

632

633

634

635

636

637

638

639

640

641

642

643

644

645

646

647

648

649

650

651

652

653

654

Ebele, A.J., Abdallah, M.A., Harrad, S. (2017). Pharmaceuticals and personal care products (PPCPs) in the freshwater aquatic environment. Emerging Contaminants, 3, 1-16.

Ghiselli, G. (2006). Avaliação das águas destinadas ao abastecimento público na região de Campinas: ocorrência e determinação dos interferentes endócrinos (IE) e produtos farmacêuticos e de higiene pessoal (PFHP). [Potable water quality in the Campinas region: occurrence and determination of endocrine disruptors (EDs) and pharmaceuticals and personal care products (PPCPs)]. pHD Thesis, UNICAMP, São Paulo, $181 \mathrm{p}$.

Ghiselli, G., Jardim, W.F. (2007). Endocrine disruptors in the environment. Química Nova, $30,695-706$.

Girardi, R., Pinheiro, A., Garbossa, L.H.P., Torres, E. (2016). Water quality change of rivers during rainy events in a watershed with different land uses in Southern Brazil. Brazilian Journal of Water Resources, 21, 514-524.

Gomes, P.I.A., Wai, O.W.H., Kularatne, R.K.A., Priyankara, T.D.P., Anojika, K.G.M.S., Kumari, G.M.N.R. (2014). Relationships Among Anthropogenic Disturbances Representative Riparian and Non-Riparian Herbaceous Indicators (Biomass and Diversity), Land Use, and Lotic Water Quality: Implications on Rehabilitation of Lotic Waters. Water Air Soil Pollution, 225: 2060.

Gomes, P.I.A., Fernando, B.A.V.W., Dehini, G.K. (2019). Assessment of Pollution Sources, Fate of Pollutants, and Potential Instream Interventions to Mitigate Pollution of Earthen Canals of Urban to Rural-Urban Fringe. Water Air Soil Pollution, 230, 262.

Gracia-Lor, E., Sancho, J.V., Serrano, R., Hernández, F. (2012). Occurrence and removal of pharmaceuticals in wastewater treatment plants at the Spanish Mediterranean area of Valencia. Chemosphere, 87(5), 453-462. 
655

656

657

658

659

660

661

662

663

664

665

666

667

668

669

670

671

672

673

674

675

676

677

Hammer, Ø., Harper, D.A.T., Ryan, P.D. (2001). PAST: Paleontological statistics software package for education and data analysis, Palaeontologia Electronica, 4, 9 p. http://palaeo-electronica.org/2001_1/past/issue1_01.htm.

Harrison, P.A., Vandewalle, M., Sykes, M.T., Berry, P.M., Bugter, R., Bello, F., Feld, C.K., Grandin, U., Harrington, R., Haslett, J.R., Jongman, R.H.G., Luck, G.W., Silva, P.M., Moora, M., Settele, J., Sousa, J.P., Zobel, M. (2010). Identifying and prioritising services in European terrestrial and freshwater ecosystems. Biodiversity Conservation, $19,2791-2821$.

Hartemink, A.E., Veldkamp, A., Bai, Z. (2008). Land cover change and soil fertility decline in tropical regions. Turkish Journal of Agriculture and Forestry, 32, 195-213.

Hem, J.D. (2012). Conductance: a collective measure of dissolved ions. Water analysis: Inorganic species, 1, 137-161.

Holbech, H., Kinnberg, K., Petersen, G.I., Jackson, P., Hylland, K., Norrgren, L., Bjerregaard, P. (2006). Detection of endocrine disrupters: evaluation of a Fish Sexual Development Test (FSDT). Comparative Biochemistry and Physiology Part C: Toxicology and Pharmacology, 144, 57-66.

Huh, J.H., Ahn, J.W. (2017). A perspective of chemical treatment for cyanobacteria control toward sustainable freshwater development. Environmental Engineering Research, 22, $1-11$.

IBGE - Instituto Brasileiro de Geografia e Estatística (2010). Pesquisa Nacional de Saneamento Básico - PNSB https://www.ibge.gov.br/estatisticas/multidominio/meioambiente/9073-pesquisa-nacional-de-saneamento-basico.html $?=\& \mathrm{t}=0$-que-e..$\quad$ Accessed 30 January 2020. 
ISO - International Organization for Standardization (2012). Method no 11269. Soil Quality Determination of the effect of pollutants on soil flora - Part 1: Method for the measurement of inhibition of root growth, $2^{\text {nd }}$ Edition. Geneva, $19 \mathrm{p}$.

Johns, S.M., Denslow, N.D., Kane, M.D., Watanabe, K.H., Orlando, E.F., Sepúlveda, M.S. (2011). Effects of estrogens and antiestrogens on gene expression of fated minnow (Pimephales promelas) early life stages. Environmental Toxicology, 26, 195-206.

Kim, S.D., Cho, J., Kim, I.S., Vanderford, B.J., Snyder, S.A. (2007). Occurrence and removal of pharmaceuticals and endocrine disruptors in South Korean surface, drinking, and wastewaters. Water Research, 41, 1013-1021.

Kohatsu, M.Y., Jesus, T.A., Coelho, L.H.G., Peixoto, D.C., Poccia, G.T., Hunter, C. (2018). Fitotoxicidade de água superficial da Região Metropolitana de São Paulo utilizando bioensaio com Sinapis alba. Acta Brasiliensis, 2(2), 58-62.

Kummerer, K. (2009). The presence of pharmaceuticals in the environment due to human use - present knowledge and future challenges. Journal of Environmental Management, 90, 2354-2366.

Leal, P.R., Moschini-Carlos, V., López-Doval, J.C., Cintra, J.P., Yamamoto, J.K., Bitencourt, M.D., Santos, R.F., Abreu, G.C., Pompêo, M.L.M. (2018). Impact of copper sulfate application at an urban Brazilian reservoir: A geostatistical and ecotoxicological approach. Science of the Total Environment, 618, 621-634.

Lienert, J., Burki, T., Escher, B.I. (2007). Reducing Micropollutants with Source Control: Substance Flow Analysis of 212 Pharmaceuticals in Faeces and Urine. Water Science and Technology, 56, 87-96.

Lima, G.N., Rueda, V.O.M. (2018). The urban growth of the metropolitan área of São Paulo and its impacto $\mathrm{n}$ the climate. Weather and Climate Extremes, 21, 17-26. 
702

703

704

705

706

707

708

709

710

711

712

713

714

715

716

717

718

719

720

721

722

723

724

725

Ling, T.Y., Gerunsin, N., Soo, C.L., Nyanti, L., Sim, S.F., Grinang, J. (2017). Seasonal Changes and Spatial Variation in Water Quality of a Large Young Tropical Reservoir and Its Downstream River. Journal of Chemistry, 2017, 16 p.

Ma, L., Yates, S.R. (2018). Degradation and metabolite formation of 17ß-estradiol-3glucuronide and 17ß-estradiol-3-sulphate in river water and sediment. Water Research, $139,1-9$.

Machado, K.S., Cardoso, F.D., Azevedo, J.C.R. (2014). Occurrence of female sexual hormones in the Iguazu river basin, Curitiba, Parana State, Brazil. Acta Scientiarum Technology, 36, 421-427.

Maldaner, L., Jardim, I.C.S.F. (2012). Determination of some organic contaminants in water samples by solid-phase extraction and liquid chromatography tandem mass spectrometry. Talanta, 100, 38-44.

Magalhães, D.P., Ferrão-Filho, A.S. (2008). A Ecotoxicologia como ferramenta no biomonitoramento de ecossistemas aquáticos. Oecologia brasiliensis, 12, 355-381.

Mariani, C.F.; Moschini-Carlos, V.; Brandimarte, A.L.; Nishimura, P.Y.; Tófoli, C.F.; Duran, D.S.; Lourenço, E.M.; Braidotti, J.C.; Almeida, L.P.; Fidalgo, V.H., Pompêo, M.L.M. (2006). Biota and water quality in the Riacho Grande reservoir, Billings Complex (São Paulo, Brazil). Acta Limnologica Brasiliensia, 18(3), 267-280.

Markewitz, D., Resende, J.C.F., Parron, L., Bustamante, M., Klink, C.A., Figuereido, R.O., Davidson, E.A. (2006). Dissolved rainfall inputs and streamwater outputs in an undisturbed watershed on highly weathered soils in the Brazilian cerrado. Hydrological Processes, 20, 2615-2639.

MEA - Millenium Ecosystem Assessment (2005). Ecosystems and human well-being: synthesis. Washington, DC: Island Press, p. 137. 
Moschini-Carlos, V., Freitas, L.G.; Pompêo, M. (2010). Limnological evaluation of water in the Rio Grande and Taquacetuba branches of the Billings Complex (São Paulo, Brazil) and management implications. Ambiente e Água - An Interdisciplinary Journal of Applied Science, 5(3), 47-59.

Nakada, N., Tanishima, T., Shinohara, H., Kiri, K., Takada, H. (2006). Pharmaceutical chemicals and endocrine disrupters in municipal wastewater in Tokyo and their removal during activated sludge treatment. Water Research, 40, 3297-3303.

Nguyen, B.T., Do, D.D., Nguyen, T.X., Nguyen, V.N., Nguyen, D.T.P., Nguyen, M.H., Truong, H.T.T., Dong, H.P., Le, A.H. \& Bach, Q.V. (2020). Seasonal, spatial variation, and pollution sources of heavy metals in the sediment of the Saigon River, Vietnam. Environmental Pollution, 256, 113412.

Padhye, L.P., Tezel, U. (2013). Fate of Environmental Pollutants. Water Environmental Research, 85, 1734-1785.

Panter, G.H., Thompson, R.S., Beredford, N., Sumpter, J.P. (1999). Transformation of a nonoestrogenic steroid metabolite to an oestrogenically active substance by minimal bacterial activity. Chemosphere, 38, 3579-3596.

Pereda, O., Solagaistua, L., Atristain, M., Guzmán, I., Larrañaga, A., von Schiller, D., Elosegi, A. (2020). Impact of wastewater effluent pollution on stream functioning: A whole-ecosystem manipulation experiment. Environmental Pollution, 258, 113719.

Pereira, L.C., Souza, A.O., Bernardes, M.F.F., Pazin, M., Tasso, M.J., Pereira, P.H., Dorta, D.J. (2015). A perspective on the potential risks of emerging contaminants to human and environmental health. Environmental Science and Pollution, 22(18), 13800-13823.

Pessoa, G.P., Souza, N.C., Vidal, C.B., Alves, J.A.C., Firmino, P.I.M., Nascimento, R.F., Santos, A.B.S. (2014). Occurrence and removal of estrogens in Brazilian wastewater treatment plants. Science of the Total Environment, 490, 288-295. 
751 Quadra, G.R., Souza, H.O., Costa, R.D., Fernandez, M.A.D. (2017). Do pharmaceuticals

752

753

754

755

756

757

758

759

760

761

762

763

764

765

766

767

768

769

770

771

772

773

774

775 reach and affect the aquatic ecosystems in Brazil? A critical review of current studies in a developing country. Environmental Science and Pollution, 24(2), 1200-1218.

Rangel-Peraza, J.G., Anda, J., González-Farias, F., Erickson, D. (2009). Statistical assessment of water quality seasonality in large tropical reservoirs. Lakes \& Reservoirs Research \& Management, 14, 315-323.

Rani, C.N., Karthikeyan, S. (2016). Endocrine disrupting compounds in water and wastewater and their treatment options - a review. International Journal of Environmental Technology Management, 19, 392-431.

Reis-Filho, R.W., Araújo, J.C., Vieira, E.M. (2006). Hormônios sexuais estrógenos: contaminantes bioativos. Química Nova, 29, 817-822.

Rodrigues, V., Estrany, J., Ranzini, M., Cicco, V., Martín-Benito, J.M.T., Hedo, J., LucasBorja, M.E. (2018). Effects of land use and seasonality on stream water quality in a small tropical catchment: The headwater of Córrego Água Limpa, São Paulo (Brazil). Science of the Total Environment, 622-623, 1553-1561.

Sabesp - Companhia de Saneamento Básico do Estado de São Paulo. (2011). Ata da Sessão Pública 58749/10. Objeto: Fornecimento de Sulfato de Cobre para Tratamento de Água - Compra Estratégica.

Sabesp - Companhia de Saneamento Básico do Estado de São Paulo (Sabesp). (2020). Dados $\operatorname{dos}$ sistemas produtores. http://mananciais.sabesp.com.br/HistoricoSistemas?SistemaId $=0$. Accessed 30 January 2020.

Scala-Benuzzi, M.L., Takara, E.A., Alderete, M., Soler-Illia, G.J.A.A., Schneider, R.J., Raba, J., Messina, G.A. (2018). Ethinylestradiol quantification in drinking water sources using a fluorescent paper based immunosensor. Microchemical Journal, 141, 287 - 293. 
Schäefer, R.B., Bundschuh, M., Rouch, D.A., Szöcs, E., von der Ohe, P.C., Pettigrove, V., Schulz, R., Nugegoda, D., Kefford, B.J. (2012). Effects of pesticide toxicity, salinity and other environmental variables on selected ecosystem functions in streams and the relevance for ecosystem services. Science of the Total Environment, 415, 69-78.

Schröder, P., Helmreich, B., Škrbić, B., Carballa, M., Papa, M., Pastore, C., Emre, Z., Oehmen, A., Langenhoff, A., Molinos, M., Dvarioniene, J., Huber, C., Tsagarakis, K.P., Martinez-Lopez, E., Meric-Pagano, S., Vogelsang, C., Mascolo, G. (2016). Status of hormones and painkillers in wastewater effluents across several European statesconsiderations for the EU watch list concerning estradiols and diclofenac. Environmental Science and Pollution Research (international), 23, 12835-12866.

Silva, E., Daam, M.A., Cerejeira, M.J. (2015). Aquatic risk assessment of priority and other river basin specific pesticides in surface waters of Mediterranean river basins. Chemosphere, 135, 394-402.

Sodré, F.F., Pescara, I.C., Montagner, C.C., Jardim, W.F. (2010). Assessing selected estrogens and xenoestrogens in Brazilian surface waters by liquid chromatographytandem mass spectrometry. Microchemical Journal, 96, 92-98.

Sousa, D.N.R., Mozeto, A.A., Carneiro, R.L., Fadini, P.S. (2014). Electrical conductivity and emerging contaminants as markers of surface freshwater contamination by wastewater. Science of the Total Environment, 484, 19-26.

Souza, V.A., Wasserman, J.C. (2015). Distribution of heavy metals in sediments of a tropical reservoir in Brazil: sources and fate. Journal of South American Earth Sciences, 63, 208-216.

Statstutor

(2020).

Pearson's

correlation. http://www.statstutor.ac.uk/resources/uploaded/pearsons.pdf. Accessed in 23 January 2020. 
801

802

803

804

805

806

807

808

809

810

811

812

813

814

815

816

817

818

819

820

821

822

823

824

Su, Y., Langhammer, J., Jarsjö, J. (2017). Geochemical responses of forested catchments to bark beetle infestation: Evidence from high frequency in-stream electrical conductivity monitoring. Journal of Hydrology, 550, 635-649.

Sui, Q., Huang, J., Deng, S., Yu, G., Fan, Q. (2010). Occurrence and removal of pharmaceuticals, caffeine and DEET in wastewater treatment plants of Beijing, China. Water Research, 44, 417-426.

Tailing, J.F. (2010). pH, the $\mathrm{CO}_{2}$ system and freshwater science. Freshwater Reviews, 3, 133146.

Tomšíková, H., Aufartová, J., Solich, P., Nováková, L., Sosa-Ferrera, Z., Santana-Rodríguez, J.J. (2012). High-sensitivity analysis of female-steroid hormones in environmental samples. Trends in Analytical Chemistry, 34, 35-58.

Thompson, M.Y., Brandes, D., Kney, A.D. (2012). Using electronic conductivity and hardness data for rapid assessment of stream water quality. Journal of Environmental Management, 104, 152-157.

Thompson, J., Pelc, C.E., Brogan, W.R., Jordan, T.E. (2018). The multiscale effects of stream restoration on water quality. Ecological Engineering, 124, 7-18.

Tran, N.H., Reinhard, M., Gin, K.Y.H. (2018). Occurrence and fate of emerging contaminants in municipal wastewater treatment plants from different geographical regions - a review. Water Research, 133, 182-207.

Trata Brasil. (2018). http://www.tratabrasil.org.br/saneamento/principais-estatisticas. Accessed in 13 November 2018.

US Forest Service. (1995). Ecosystem analysis at the watershed scale: federal guide for watershed analysis. watershed scale: federal guide for watershed analysis. Version 2.2, Regional Interagency Executive Committee: Regional Ecosystem Office, U.S. 
Government; 26 p. https://www.fs.fed.us/r6/reo/library/docs/watershd.pdf. Accessed in 30 January 2020 .

USEPA - United States Environmental Protection Agency. (2010). Method 539: Determination of Hormones in Drinking Water by Solid Phase Extraction (SPE) and Liquid Chromatography Electrospray Ionization Tandem Mass Spectrometry (LC-ESIMS/MS). 37 p. Accessed in 30 January 2020.

USEPA - United States Environmental Protection Agency. (2012). Monitoring Unregulated Drinking Water Contaminants. https://www.epa.gov/dwucmr/third-unregulatedcontaminant-monitoring-rule. Accessed in 17 December 2018.

van den Belt, K., Berckmans, P., Vangenechten, C., Verheyen, R., Witters, H. (2004). Comparative study on the in vitro/in vivo estrogenic potencies of 17-estradiol, estrone, 17-ethynylestradiol and nonylphenol. Aquatic Toxicology, 66, 183-195.

Vieira, L.A. (2016). Compostagem de biossólido de estação de tratamento de efluentes de frigorífico com serragem e cama de aves. [Composting of biosolids from wastewater treatment plant with sawdust and poultry litter]. Master Dissertation, Universidade Federal de Pelotas, Rio Grande do Sul, 66 p.

Vymazal, J., Brezinová, T., Kozeluh, M. (2015). Occurrence and removal of estrogens, progesterone and testeosterone in three constructed wetlands treating municipal sewage in the Czech Republic. Science of the Total Environment, 536, 625-631.

Weijs, S.V., Mutzner, R., Parlange, M.B. (2013). Could electrical conductivity replace water level in rating curves for alpine streams? Water Resource Research, 49(1), 343-351.

Wengrat, S., Bicudo, D.C. (2011). Spatial evaluation of water quality in an urban reservoir (Billings Complex, southeastern Brazil). Acta Limnologica Brasiliensia [online], 23(2), 200-216. 
849 WHO - World Health Organization. (2003). Chloride in Drinking-water: Background 850 document for development. WHO Guidelines for Drinking-water Quality.

851 Yongming, H., Peixuan, D., Junji, C., Posmentier, E.S. (2006). Multivariate analysis of heavy 852 metal contamination in urban dusts of Xi'an, Central China. Science of the Total 853 Environment, 355, 176-186.

854 Ziemer, R.R. (1998). Monitoring Watersheds and Streams. USDA Forest Service Gen. Tech. 855 Rep. PSW-GTR-168, 6 p. https://www.fs.fed.us/psw/publications/documents/gtr$856 \quad$ 168/15ziemer.pdf. Accessed in 30 January 2020.

857 Zuccato, E., Castiglioni, S., Fanelli, R., Reitano, G., Bagnati, R., Chiabrando, C., Pomati, F., 858 Rossetti, C., Calamari, D. (2005). Pharmaceuticals in the Environment in Italy: Causes, 859 Occurrence, Effects and Control. Environmental Science Pollution Research 860 (International), 13(1), 15-21. 
Table 1. Sampling stations coordinates and description (IBGE 2010, Trata Brasil 2018).

\begin{tabular}{|c|c|c|}
\hline $\begin{array}{c}\text { Sampling } \\
\text { Station }\end{array}$ & Coordinates & Description \\
\hline S1 & $\begin{array}{l}-23,7150 \mathrm{~S} \\
-46,4294 \mathrm{~W}\end{array}$ & $\begin{array}{l}\text { A pristine area of the Rio Grande Branch considered as reference at present study. There is no direct } \\
\text { disposal of effluents and it is used for bathing and amateur fishing by nearby resident. Average depth is } 10 \\
\text { m. Presence of native vegetation and aquatic macrophytes in some periods. }\end{array}$ \\
\hline $\mathbf{S 2}$ & $\begin{array}{l}-23,7511 \mathrm{~S} \\
-46,4694 \mathrm{~W}\end{array}$ & $\begin{array}{l}\text { Water abstraction point for drinking water supply located in São Bernardo do Campo municipality. } \\
\text { Densely occupied area with precarious urbanization. Application of copper-based algaecides to avoid algal } \\
\text { bloom. }\end{array}$ \\
\hline S3 & $\begin{array}{l}-23,7714 \mathrm{~S} \\
-46,4750 \mathrm{~W}\end{array}$ & $\begin{array}{l}\text { Ribeirão Pires stream that receives raw sewage from the municipality of Ribeirão Pires with a population } \\
\text { of around } 122.000 \text { inhabitants of which only approximately } 14 \% \text { is connected to a sewer. This stream has } \\
\text { about } 10 \mathrm{~m} \text { width and } 3 \mathrm{~m} \text { depth and enters the Rio Grande Branch from the North-East. The sampling } \\
\text { spot was on a bridge that crosses the stream next to a residential neighborhood that dumps sewage directly } \\
\text { into the water body. Presence of solid waste at the borders. }\end{array}$ \\
\hline S4 & $\begin{array}{l}-23,7692 \mathrm{~S} \\
-46,5322 \mathrm{~W}\end{array}$ & $\begin{array}{l}\text { Tubarão stream that receives treated effluent from Parque Andreense Wastewater Treatment Plant } \\
\text { (WWTP). This WWTP uses activated sludge technology and treats around } 80 \% \text { of the wastewater from } \\
\text { the Parque Andreense neighborhood in Santo André-SP, amounting to a population of around } 5,000 \\
\text { inhabitants. WWTP do not include tertiary treatment step, thus disposing high amounts of Phosphorus into } \\
\text { the water body. The sampling spot was in a water column of about } 20 \text {-cm depth close to a community with } \\
20 \text { residences that directly dispose wastewater on the stream. }\end{array}$ \\
\hline
\end{tabular}


862 Table 2. Estrogenic hormones concentrations and standard deviation $\left(\mathrm{ng} \mathrm{L}^{-1}\right)$ in surface 863 waters of Metropolitan Area of São Paulo, MASP, Brazil (n = 3).

\begin{tabular}{|c|c|c|c|c|c|c|}
\hline \multirow{2}{*}{$\begin{array}{c}\text { Sampling } \\
\text { stations }\end{array}$} & \multicolumn{3}{|c|}{ DRY PERIOD } & \multicolumn{3}{|c|}{ WET PERIOD } \\
\hline & $\begin{array}{l}\text { Sampling } \\
\text { campaigns }\end{array}$ & $\begin{array}{c}\text { E2 } \\
\left(\mathrm{ng} \mathrm{L}^{-1}\right)\end{array}$ & $\begin{array}{c}\text { EE2 } \\
\left(n g L^{-1}\right)\end{array}$ & $\begin{array}{l}\text { Sampling } \\
\text { campaigns }\end{array}$ & $\begin{array}{c}\text { E2 } \\
\left(\mathrm{ng} \mathrm{L}^{-1}\right)\end{array}$ & $\begin{array}{c}\text { EE2 } \\
\left(\mathrm{ng} \mathrm{L}^{-1}\right)\end{array}$ \\
\hline S1 & \multirow{4}{*}{ DI } & $<\mathrm{LOQ}$ & $<$ LOQ & \multirow{4}{*}{ WI } & $<$ LOQ & $<$ LOQ \\
\hline S2 & & $860 \pm 120$ & $630 \pm 80$ & & $<\mathrm{LOQ}$ & $<\mathrm{LOQ}$ \\
\hline S3 & & $1,700 \pm 300$ & $1,200 \pm 140$ & & $180 \pm 50$ & $300 \pm 90$ \\
\hline S4 & & $<\mathrm{LOQ}$ & $200 \pm 80$ & & $<\mathrm{LOQ}$ & $250 \pm 100$ \\
\hline S1 & \multirow{4}{*}{ DII } & $<$ LOQ & $<$ LOQ & \multirow{4}{*}{ WII } & $<\mathrm{LOQ}$ & $<$ LOQ \\
\hline S2 & & $<\mathrm{LOQ}$ & $<\mathrm{LOQ}$ & & $890 \pm 240$ & $<\mathrm{LOQ}$ \\
\hline S3 & & $160 \pm 30$ & $460 \pm 100$ & & $250 \pm 80$ & $<\mathrm{LOQ}$ \\
\hline S4 & & $710 \pm 160$ & $340 \pm 80$ & & $630 \pm 130$ & $320 \pm 120$ \\
\hline S1 & \multirow{4}{*}{ DIII } & $<\mathrm{LOQ}$ & $<\mathrm{LOQ}$ & \multirow{4}{*}{ WIII } & $<\mathrm{LOQ}$ & $<\mathrm{LOQ}$ \\
\hline S2 & & $<\mathrm{LOQ}$ & $<$ LOQ & & $900 \pm 110$ & $210 \pm 90$ \\
\hline S3 & & $120 \pm 30$ & $<\mathrm{LOQ}$ & & $140 \pm 50$ & $210 \pm 80$ \\
\hline S4 & & $300 \pm 80$ & $120 \pm 30$ & & $1,720 \pm 560$ & $250 \pm 100$ \\
\hline S1 & \multirow{4}{*}{ DIV } & $<$ LOQ & $<$ LOQ & \multirow{4}{*}{ WIV } & $<$ LOQ & $<$ LOQ \\
\hline S2 & & $<\mathrm{LOQ}$ & $<$ LOQ & & $<\mathrm{LOQ}$ & $<$ LOQ \\
\hline S3 & & $360 \pm 90$ & $450 \pm 30$ & & $450 \pm 130$ & $240 \pm 90$ \\
\hline S4 & & $<\mathrm{LOQ}$ & $650 \pm 120$ & & $870 \pm 150$ & $<\mathrm{LOQ}$ \\
\hline S1 & \multirow{4}{*}{$\begin{array}{l}\text { Number of } \\
\text { occurrences }\end{array}$} & 0 & 0 & \multirow{4}{*}{$\begin{array}{l}\text { Number of } \\
\text { occurrences }\end{array}$} & 0 & 0 \\
\hline S2 & & 1 & 1 & & 2 & 1 \\
\hline S3 & & 4 & 3 & & 4 & 3 \\
\hline S4 & & 2 & 4 & & 3 & 3 \\
\hline
\end{tabular}




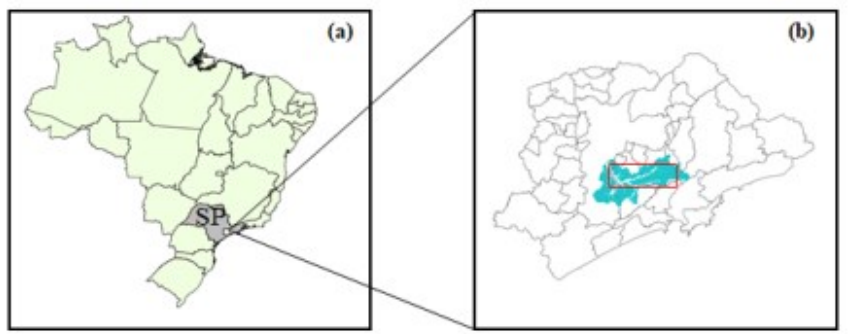

(c)

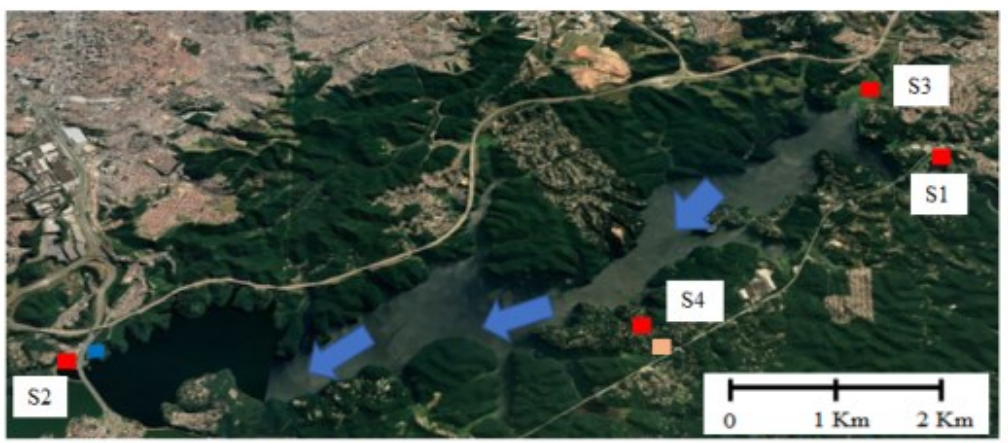

- Sample stations
Wastewater Treatment Plant Pq. Andreense
Water Abstraction by Sabesp
Water flow
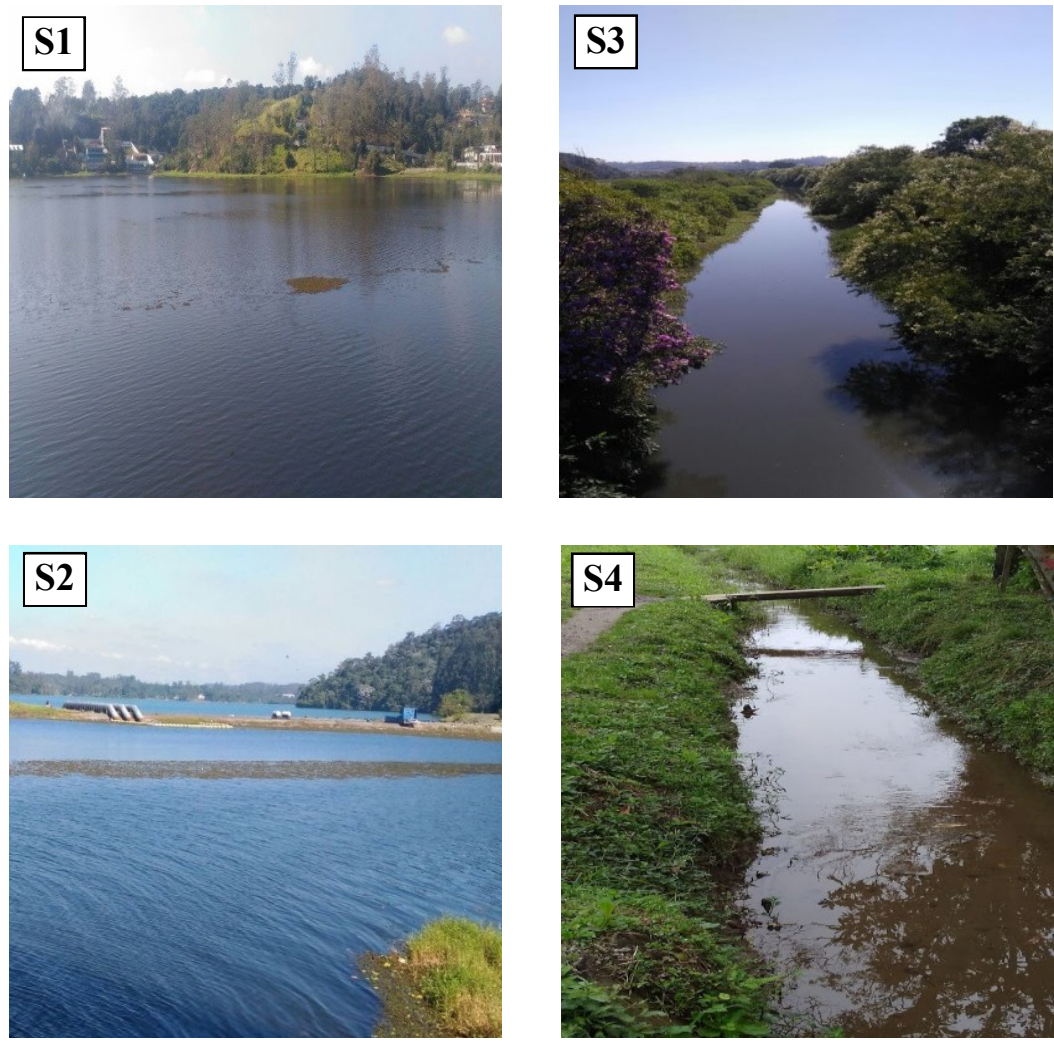

Figure 1. Study area location: (a) São Paulo State in Brazil; (b) Metropolitan Area of São

867 Paulo and Billings Reservoir; (c) Sampling stations on the Rio Grande Branch. 


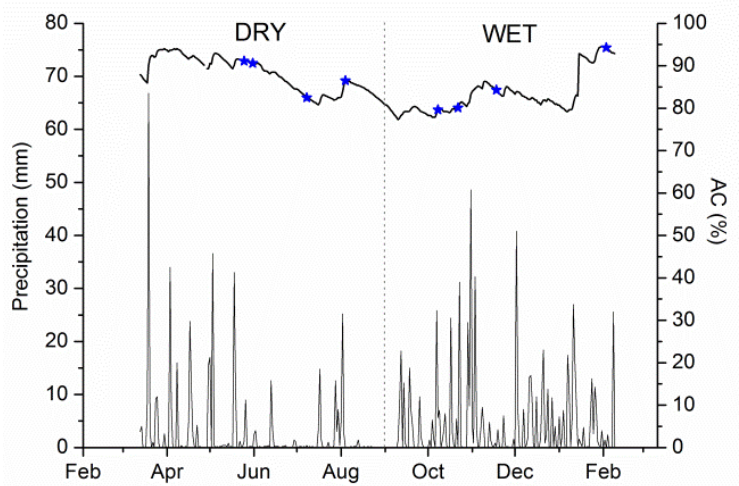

Figure 2. Precipitation (mm) at the studied area and Rio Grande Active Capacity (AC, $\%)$ in dry and wet seasons. Stars on the AC plot indicate sampling dates. 

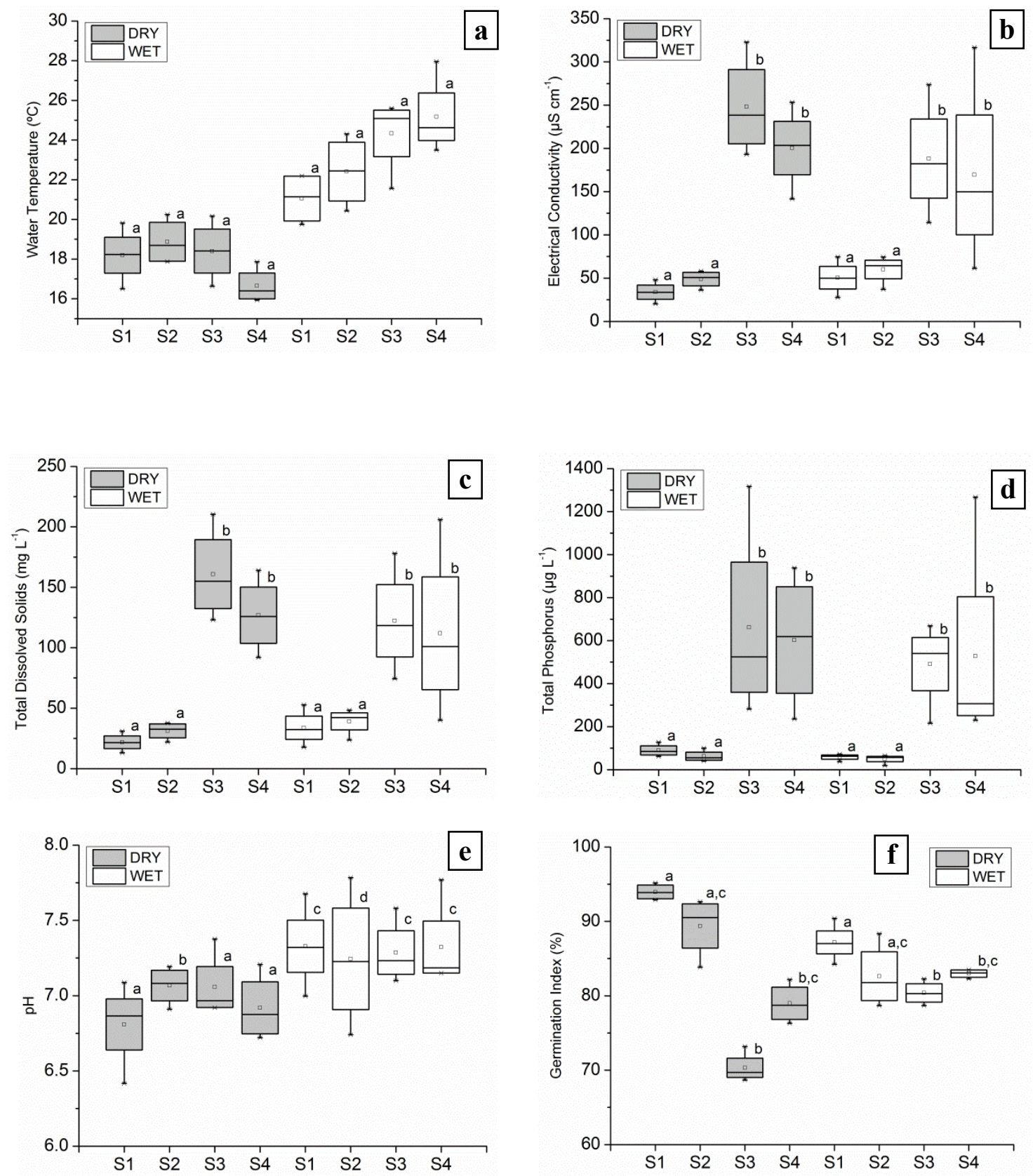

870 Figure 3. Boxplot of (a) Water temperature $\left({ }^{\circ} \mathrm{C}\right)$; (b) EC ( $\left.\mu \mathrm{S} \mathrm{cm}^{-1}\right)$, (c) TDS (mg L $\left.{ }^{-1}\right)$; (d) TP

$871\left(\mu \mathrm{g} \mathrm{L}^{-1}\right)$; (e) $\mathrm{pH}$; (f) GI (\%) in dry and wet periods, over the four sampling campaigns. 


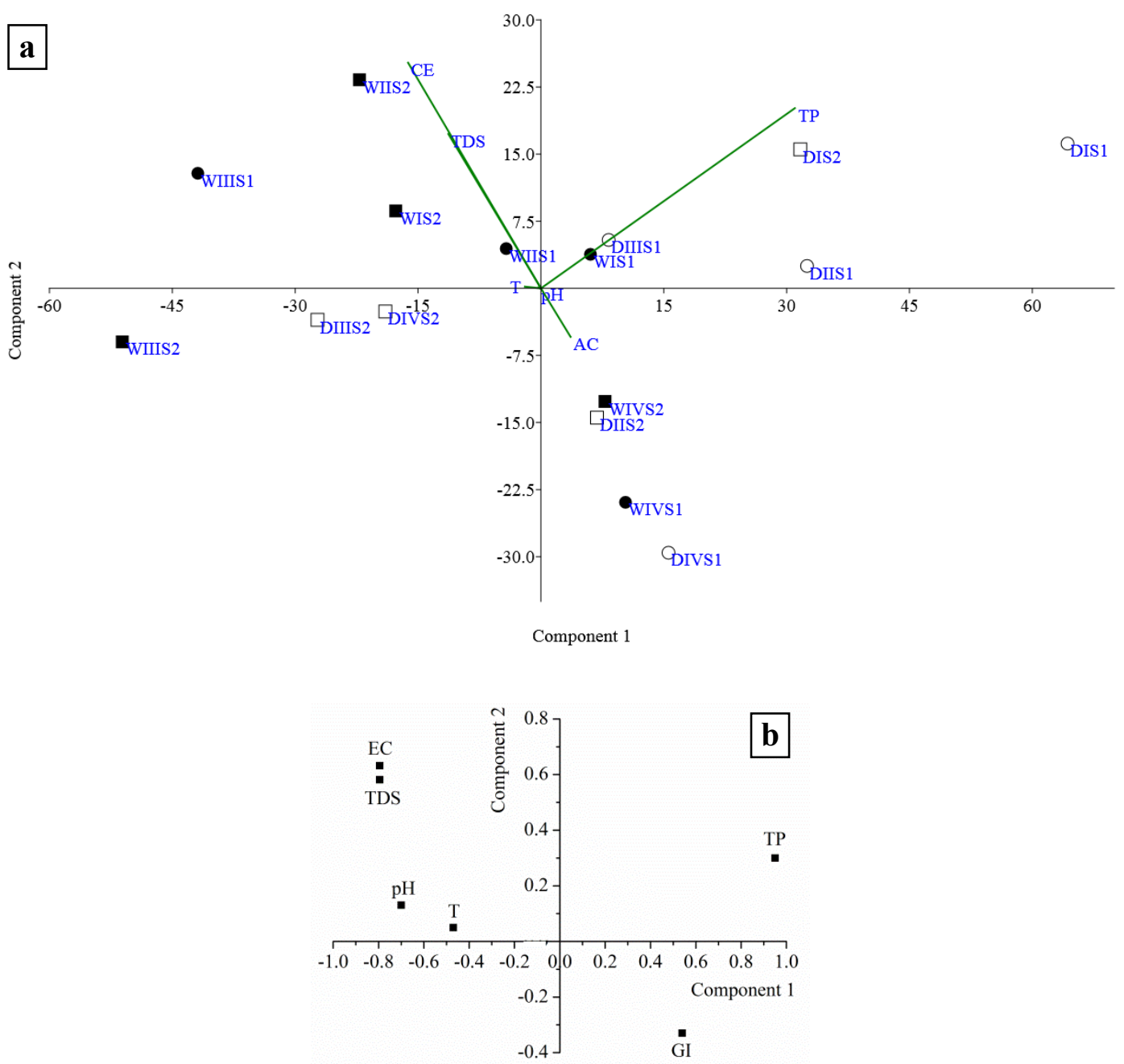

873 Figure 4. PCA scores (a) and loadings (b) for samples and variables studied at reservoir 874 stations (S1 and S2). 

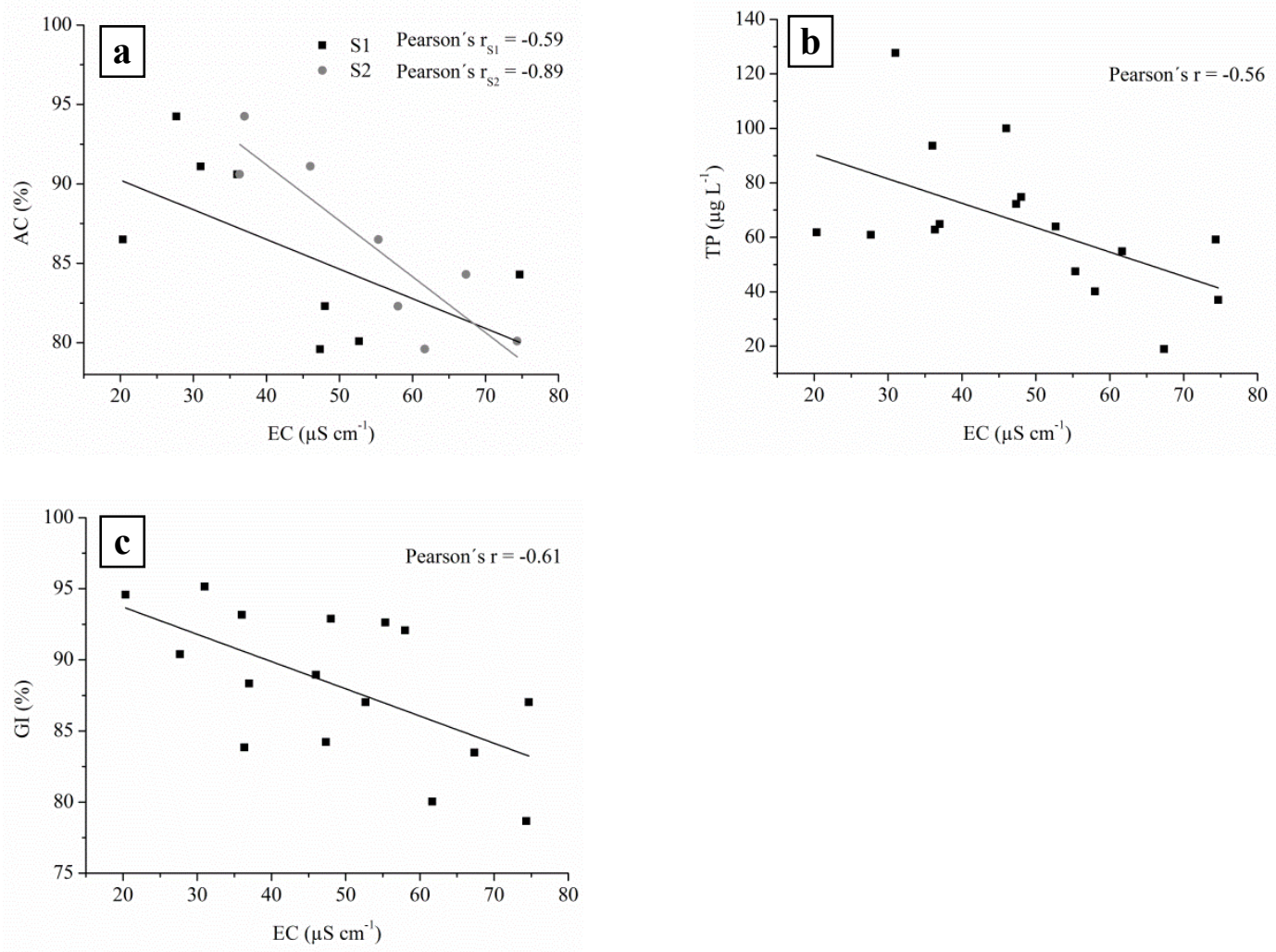

876 Figure 5. Pearson's correlations of EC ( $\left.\mu \mathrm{s} \mathrm{cm}^{-1}\right)$ with: a) AC (\%); b) TP $\left(\mu \mathrm{g} \mathrm{L}^{-1}\right)$ and c) GI $877(\%)$ in reservoir stations (S1 and S2). 

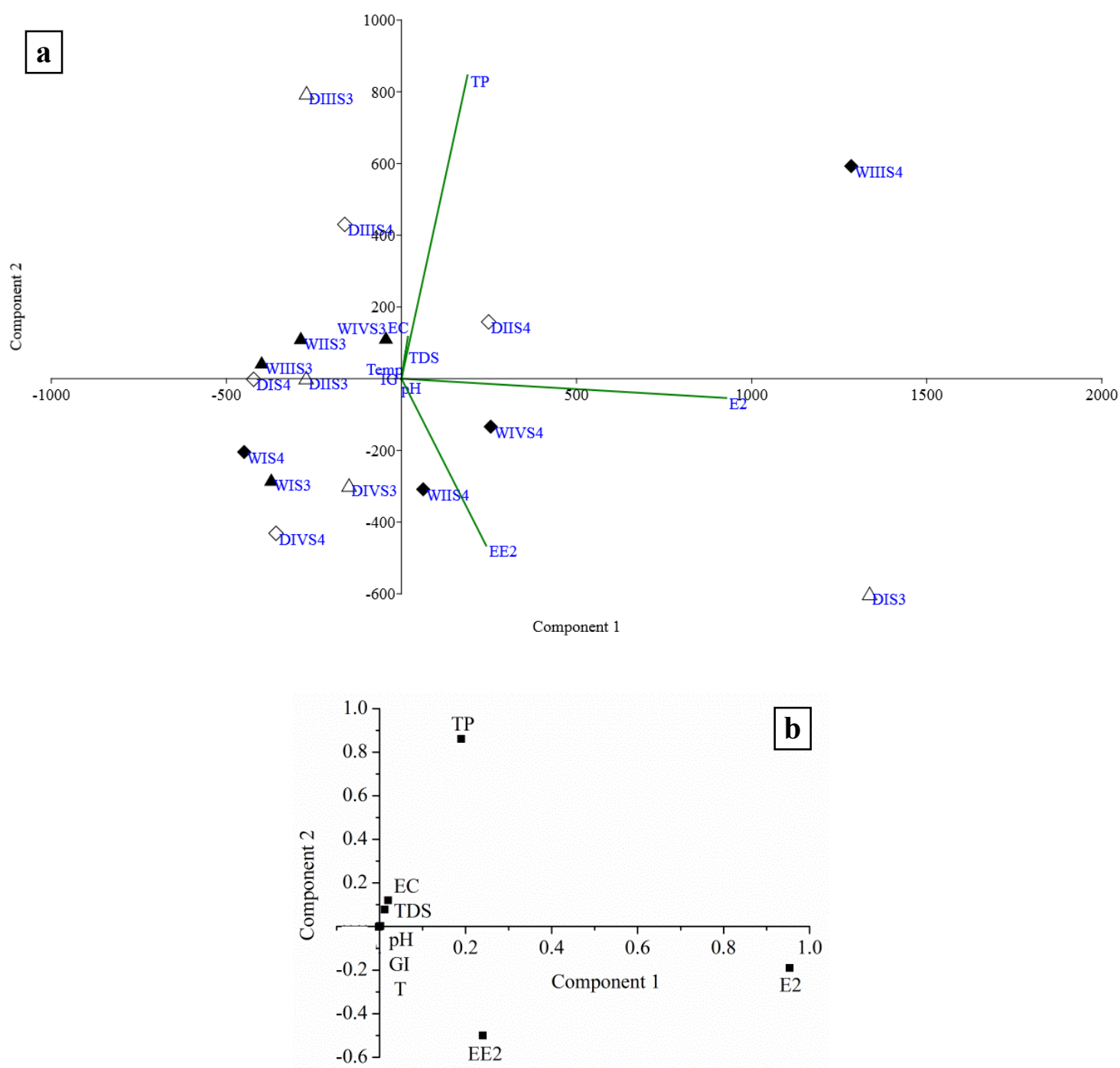

879 Figure 6. PCA for stream stations (S3 and S4): (a) Biplot scores (b) Loadings.
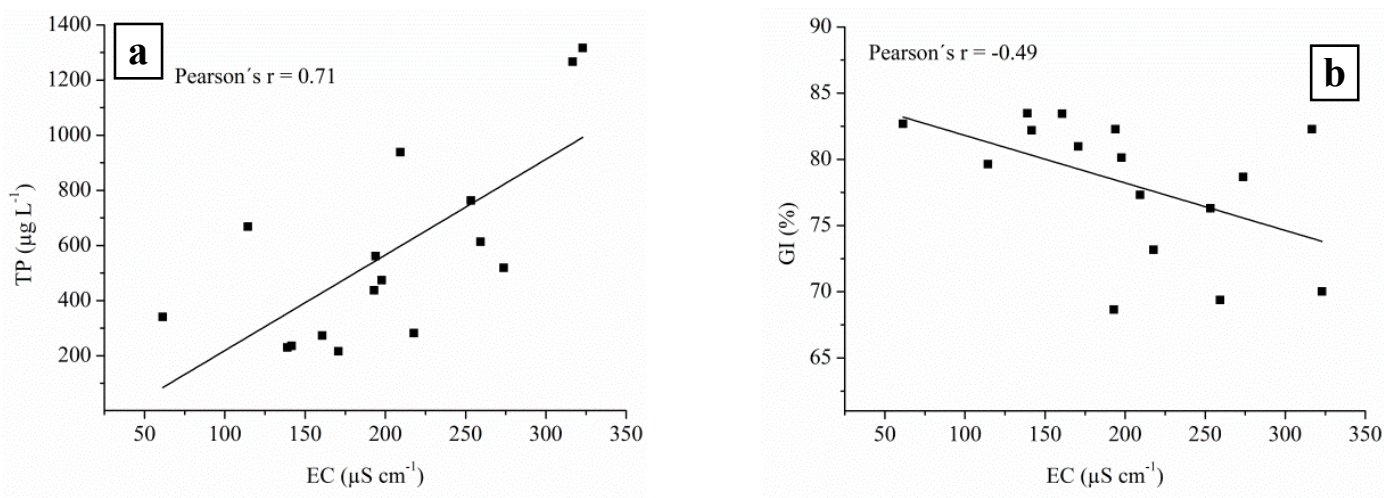

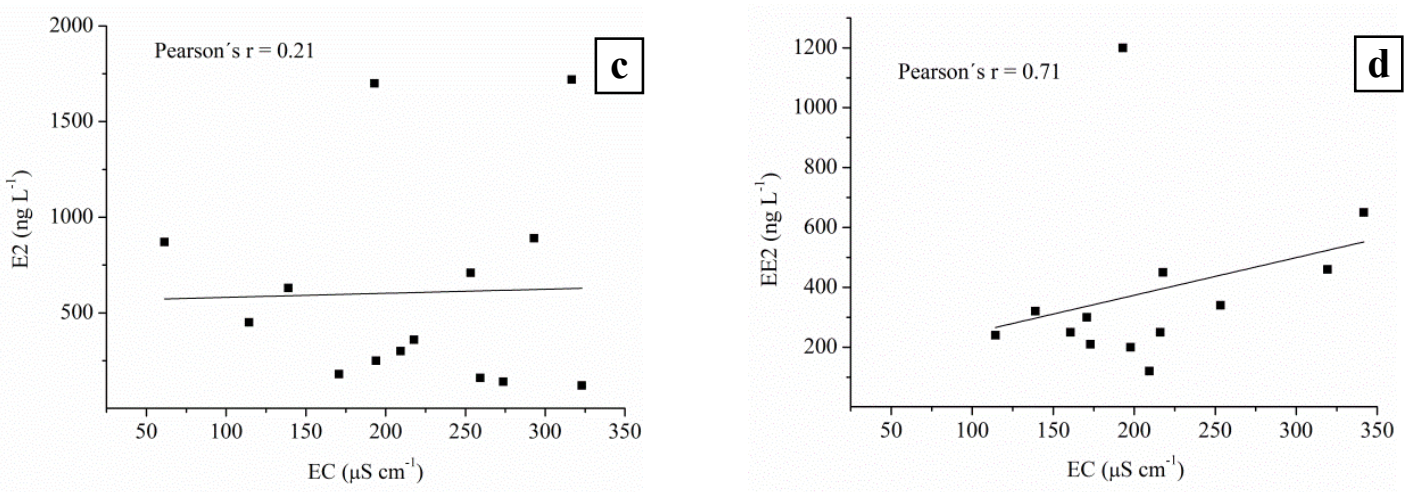

880 Figure 7. Pearson's correlations of Electrical conductivity with environmental data to stream 881 stations (S3 and S4): (a) TP ( $\left.\mu \mathrm{g} \mathrm{L}^{-1}\right)$; (b) GI (\%); (c) E2 (ng L $\left.{ }^{-1}\right)$; (d) EE2 (ng L $\left.{ }^{-1}\right)$. 

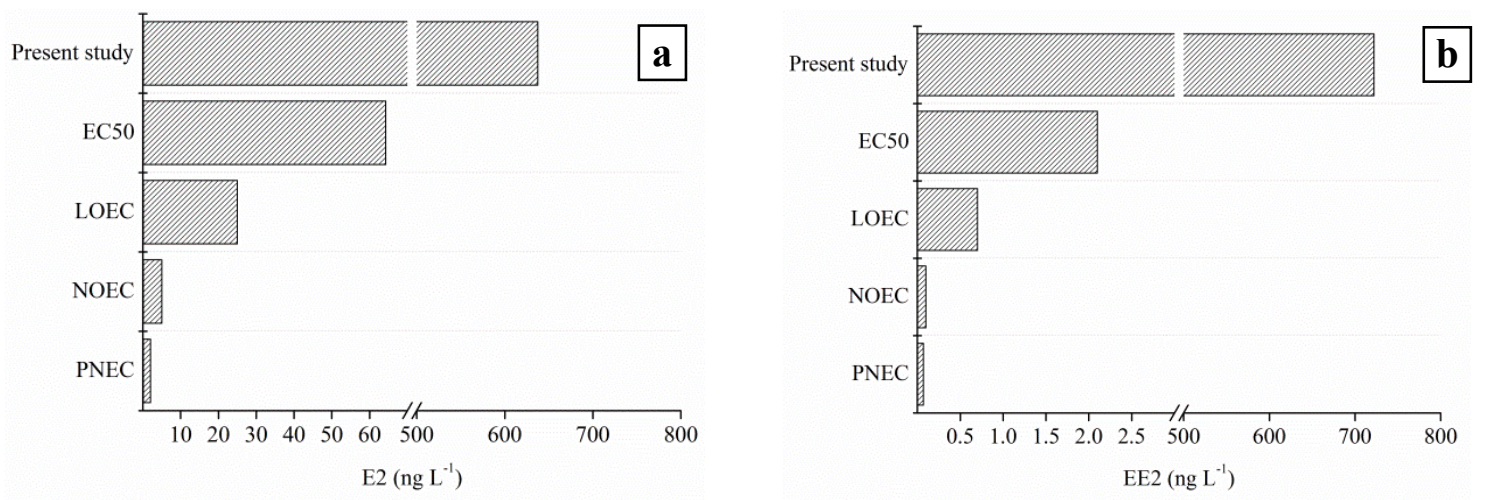

883 Figure 8. E2 (a) and EE2 (b) levels and risk assessment for PNEC (Caldwell et al. 2012);

884 NOEC (Aris et al. 2014); LOEC (Aris et al. 2014) and $\mathrm{EC}_{50}$ (van den Belt et al. 2004). 